\title{
4. MESOZOIC SEISMIC STRATIGRAPHY AND TECTONIC EVOLUTION OF THE WESTERN EXMOUTH PLATEAU ${ }^{1}$
}

\author{
Neville F. Exon ${ }^{2}$ and Richard T. Buffler ${ }^{3}$
}

\begin{abstract}
The western corner of the continental Exmouth Plateau is bounded by Early Cretaceous (ValanginianHauterivian) abyssal plains on two sides. A study of a regional grid of reflection seismic profiles, in conjunction with the results from ODP Sites 762, 763, and 766, has helped us elucidate the Triassic to Late Cretaceous history of the region.

Before late Mesozoic continental breakup, this area was part of northern Gondwana facing Tethys, and was subject to detrital, largely fluviodeltaic sedimentation. Several thousand meters of Triassic fluviodeltaic sediments were cut by strike-slip and normal faults in latest Triassic to Late Jurassic times. Near the western margin the Triassic sediments give way to a volcanic sequence, of inferred latest Triassic to earliest Jurassic age, parts of which were planated near sea level in and before the early Neocomian. The detritus from the early Neocomian erosion formed a shallow-marine sediment body in the west, $90 \mathrm{~km}$ long and up to $500 \mathrm{~m}$ thick, equivalent to the Barrow Group in the east. In the southeast in the Berriasian, the top Triassic unconformity was overlain by up to $1500 \mathrm{~m}$ of prodelta muds of the Barrow delta (deposited in 6 m.y.) prograding northward. These were derived largely from an uplifted area, formed by Neocomian thermal doming along the Cape Range Fracture Zone, and also along the zone of later rifting farther southeast.

Late Valanginian breakup led to the movement of Greater India away to the west, by rifting on the northwestern side of the plateau and by shearing along the Cape Range Fracture Zone on the southwestern side. On the plateau, after a Valanginian hiatus, there was slow detrital sedimentation as the plateau sank, and by Late Cretaceous times bathyal carbonates were being deposited. Postbreakup sediments are generally less than $1000 \mathrm{~m}$ thick. On the new abyssal plains sedimentation was in increasingly deep water. During the late Valanginian to Hauterivian, grain-flow sands and silts were deposited on oceanic basalt close to the plateau, while abyssal muds were deposited farther away. In the mid-Cretaceous, pelagic sediments and carbonate turbidites replaced the grain-flow sands, silts, and muds. The postbreakup sediments on the abyssal plain are 400-500 m thick.
\end{abstract}

\section{INTRODUCTION}

The Exmouth Plateau (Fig. 1) is a thinned and subsided continental block about $20 \mathrm{~km}$ thick, consisting of roughly equal proportions of crystalline crust and sedimentary strata (Willcox and Exon, 1976). The sedimentary strata were deposited in part of the North Carnarvon Basin (Hocking et al., 1987; Cockbain, 1989) and are believed to consist of $5000 \mathrm{~m}$ of Paleozoic rocks (not yet sampled), an average of $3000 \mathrm{~m}$ of Triassic sediments, generally thin Jurassic sediments, $1000 \mathrm{~m}$ of Neocomian sediments, and $700 \mathrm{~m}$ of younger Cretaceous and Cenozoic sediments (Exon and Willcox, 1978, 1980). The Paleozoic to Jurassic section consists of nonmarine to shelf sediments, Neocomian sediments are largely shelf to uppermost bathyal detrital rocks, and later Early Cretaceous age sediments are shallow-marine claystones and marls. Late Cretaceous and Cenozoic sediments are chalks and carbonate oozes. The Mesozoic sequences were deposited on the southern margin of Tethys in the Westralian Superbasin (Yeates et al., 1986; Bradshaw et al., 1988), a paralic to shallow-marine basin extending along much of Australia's Northwest Shelf.

The western Exmouth Plateau (Figs. 1 and 2) lies at the junction of the northwestern and southwestern plateau margins, and water depths are generally $1500-2500 \mathrm{~m}$. The continental slope drops northwestward toward the Gascoyne

\footnotetext{
${ }^{1}$ von Rad, U., Haq, B. U., et al., 1992. Proc. ODP, Sci. Results, 122 College Station, TX (Ocean Drilling Program).

2 Bureau of Mineral Resources, P.O. Box 378, Canberra, ACT, 2601, Australia.

${ }^{3}$ University of Texas Institute for Geophysics, 8701 MOPAC Blvd., Austin, Texas 78759-8345, U.S.A.
}

Abyssal Plain and southwestward toward the Cuvier Abyssal Plain. This paper uses reflection seismic and other data to outline the Mesozoic tectonic and sedimentary history of the western Exmouth Plateau and adjacent abyssal plains in the area that includes Ocean Drilling Program (ODP) Sites 762, 763 , and 766. It is complementary to papers on the sedimentology of Sites 762 and 763 (Exon et al., this volume, chapter 12), the palynology of the sites (Brenner, this volume, chapter 31), the detailed seismic stratigraphy near and east of the sites (Boyd et al., this volume), the sediments of Site 766 (Ludden, Gradstein, et al., 1990), and the seismic stratigraphy of the area around Site 766 (Buffler et al., in press). The Carnarvon Basin nomenclature of Hocking et al. (1987) is applied to the plateau sequences discussed here. We use the time scale of Haq et al. (1987).

The western Exmouth Plateau and adjacent abyssal plains (Fig. 1) were reasonably well understood geologically before Legs 122 and 123 . However, the drilling of fully cored holes on the crest of the plateau (Sites 762 and 763) and on the oldest oceanic crust in the Gascoyne Abyssal Plain (Site 766) and their linkage to the regional reflection seismic grid have enabled that understanding to be further developed.

\section{Previous Studies}

The Exmouth Plateau and adjacent abyssal plains have been extensively studied in several phases by academic and government institutions and by the petroleum industry. Academic work has continued from the late 1960s until the present day, but petroleum exploration was limited to a few years in the late 1970 s and early 1980 s. Modern physiographic studies commenced with that of Falvey and Veevers (1974). The results of reflection seismic surveys of the Exmouth Plateau 


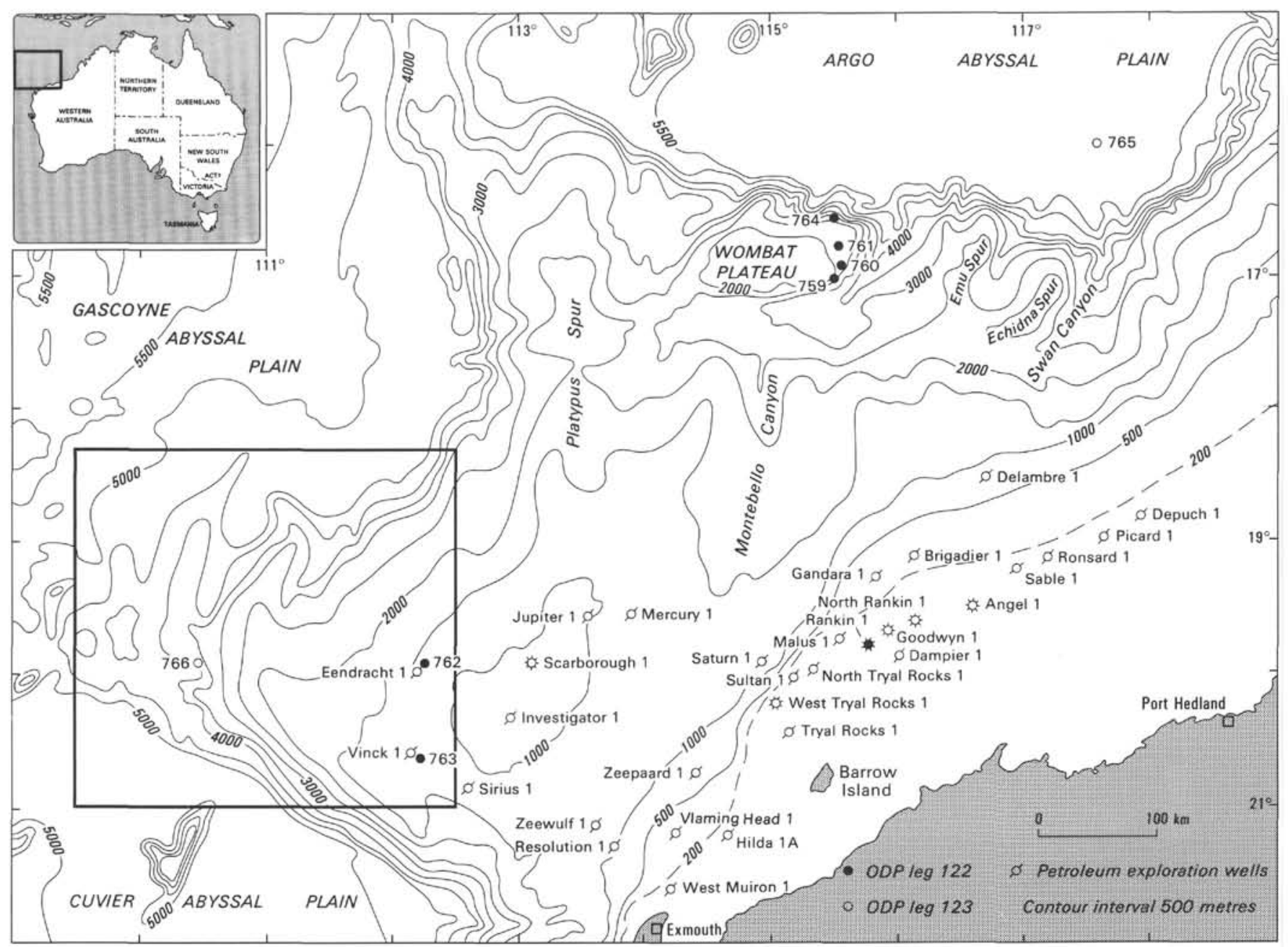

Figure 1. Exmouth Plateau bathymetric map showing the location of Sites 762, 763, and 766 and commercial petroleum exploration wells, with the area of this study boxed.

by academic institutions and the Australian Bureau of Mineral Resources (BMR) were synthesized by Willcox and Exon (1976) and Exon and Willcox (1978, 1980). The magnetic lineations on the Gascoyne and Cuvier abyssal plains have been studied by Markl (1974), Larson (1977), Larson et al. (1979), Veevers et al. (1985), and Fullerton et al. (1989). Deep Sea Drilling Project (DSDP) results from the Gascoyne and Cuvier abyssal plains were reported by Veevers, Heirtzler, et al. (1974).

The results of petroleum exploration on and near the plateau have been outlined by Powell (1976), Wright and Wheatley (1979), Cook et al. (1985), Barber (1982, 1988), Erskine and Vail (1988), and Purcell and Purcell (1988). Sedimentary and tectonic analyses relevant to this paper include those of Johnson et al. (1976), Veevers and Cotterill (1979), von Stackelberg et al. (1980), Exon et al. (1982), von Rad and Exon (1983), Veevers (1988), Powell et al. (1988), Mutter et al. (1989), Williamson et al. (1990), and Boote and Kirk (1989).

\section{Data Base}

This study makes use of bathymetric, geophysical, and borehole data. The bathymetric data used come from the GEBCO 1:1,000,000 scale plotting sheets. The geophysical data used (largely reflection seismic data) are mostly on open file at the Western Australian Department of Mines and BMR and include the following (Fig. 2):

BMR 1972 Continental Margins Program Survey 17 seismic profiles, recorded 6 -fold by Compagnie Générale de Géophysique.

Esso Australia Ltd. multichannel marine seismic survey of the Indian Ocean, offshore Western Australia, E71A, 19711972.

Gulf Research and Development Co. and Australian Gulf Oil Co. regional geophysical reconnaissance off the north coast of Western Australia, conducted with the Gulfrex in 1972. Multichannel seismic lines are included.

Shell Development (Australia) Pty. Ltd. marine geophysical survey offshore Australia, conducted with the Petrel in 1971. Multichannel seismic lines are included.

Lamont-Doherty Geological Laboratory (LDGO) singlechannel Vema 33-08 seismic profiles recorded in 1976.

BMR surveys 55 and 56 used Rig Seismic to record 48-channel seismic profiles in 1986 (Exon and Williamson, 1988).

BMR and LDGO used Rig Seismic and Robert D. Conrad to record wide-angle, common depth point (WACDP) seismic profiles in 1986 (Falvey and Williamson, 1988).

JOIDES Resolution single-channel seismic profiles were recorded in 1988. 


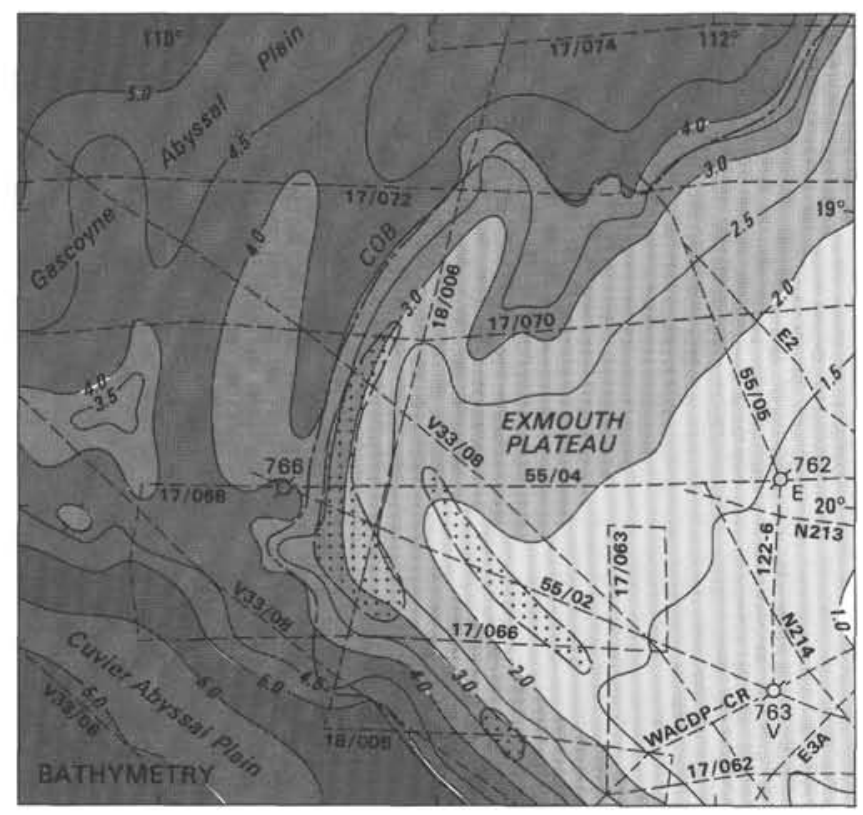

Flat erosional surface $100 \mathrm{~km}$ at depth

---- Seismic reflection ships'tracks

Figure 2. Bathymetric map of the western Exmouth Plateau, showing seismic profiles used in this study. V33 = Vema cruise 33;17, 18, and $55=$ BMR cruises 17,18 , and $55 ; \mathrm{E}=$ Esso scientific cruise; $\mathrm{N}=$ Shell Petrel cruise; $122=$ ODP Leg 122; WACDP-CR = BMR/LDGO deep crustal seismic line. Sites 762, 763, 766 and Esso exploration wells Vinck (V) and Eendracht (E) are shown. Depth contours in thousands of meters. The stipple shows the eroded top of volcanic basement highs, well below the seabed (see also Figs. 9, 10, and 11). $\mathrm{COB}=$ continent/ocean boundary.

Borehole data used include basic data from Esso Vinck No. 1 and Eendracht No. 1 petroleum exploration wells, released by the Western Australian Department of Mines, and data (Figs. 3 and 4) from Sites 762, 763, and 766 (von Rad et al., 1989; Haq, von Rad, O'Connell, et al., 1990; Leg 123 Shipboard Scientific Party, 1988; Ludden, Gradstein, et al., 1990). The ODP sites were fully cored, and some wireline logs were also run. On the plateau, the exploration wells penetrated deep into the Triassic, but the ODP sites stopped in the lower part of the early Neocomian-age Barrow Group. The Eendracht No. 1 well and adjacent Site 762 can be combined to form a composite site, as can the Vinck No. 1 well and Site 763. Figure 3 combines information from Sites 762 and 763 and Vinck No. 1, using the thickest sections drilled.

\section{Overall Tectonic Evolution}

In Paleozoic times the Exmouth Plateau was an integral part of Gondwana and surrounded by continental crust. In the Permian, the Tethys Ocean started to form to the north (Pigram and Panggabean, 1984; Şengör, 1985; Scotese, 1986; Audley-Charles, 1988; Görür and Sengör, this volume) and there was considerable stretching and thinning of the Exmouth Plateau crust (Mutter et al., 1989; Williamson et al., 1990). This led to rapid subsidence, and the deposition of a thick section of largely fluviodeltaic Triassic sediments. These sediments were cut by numerous steeply dipping faults during latest Triassic to Late Jurassic rifting. There was little subsid- ence or deposition on the central and western plateau in the Jurassic.

Breakup at the northern margin of the plateau in the Late Jurassic (Ludden, Gradstein, et al., 1990) may have been related to the final movements on the major faults on most of the western plateau. Uplift to the south in the early Neocomian led to progradation of a massive delta across the southern plateau. Breakup of the northwestern and southwestern margins, which began in the late Valanginian, formed the Gascoyne and Cuvier abyssal plains, and the flow of detrital sediments to the plateau decreased greatly. The plateau started to subside and its later history is one of slow sedimentation with decreasing detrital input.

\section{Bathymetry}

Figure 2 is a bathymetric map of the western Exmouth Plateau region, which also shows the relationship of the ODP drill sites to the reflection seismic profiles used in this study. The upper plateau dips gently northwestward from Sites 762 and 763, and small-scale Cenozoic faults apparently reach the surface in places (Figs. 5, 6, and 7). The outer $50 \mathrm{~km}$ of the northwestern margin forms a terrace (Fig. 6) or a ridge (Fig. 7), which corresponds to a change from the underlying Triassic sediments to volcanic basement. The terrace or ridge gives way to a steeper slope ( $3^{\circ}$ average), and this gives way, in turn, to a very steep, straight, abrupt, north-northeast-trending scarp, beyond which lies Site 766. On the northwestern margin, the top of the scarp is at about $3000 \mathrm{~m}$, and its base at about $4000 \mathrm{~m}$. A major canyon separates the north-northeasttrending part of the margin from the northeast-trending part farther north.

The straight southwestern margin has a ridge above volcanic basement (flat erosional surface in Fig. 2), and beyond that drops away evenly along a scarp above the Cuvier Abyssal Plain. The scarp has its top at about $2000 \mathrm{~m}$, its base at about $5000 \mathrm{~m}$, and an average slope of $5^{\circ}$. It formed tectonically along the Neocomian Cape Range Fracture Zone.

Major volcanic edifices rise from the Gascoyne Abyssal Plain, which has a maximum depth of $5500 \mathrm{~m}$, as a ridge extending northward from Site 766 and as an irregular seamount rising to less than $3500 \mathrm{~m}$ depth, west of Site 766 . The Cuvier Abyssal Plain is comparatively flat in the area of Figure 2, although a gentle rise (just less than $5000 \mathrm{~m}$ deep) trends west-northwest in the southwestern corner of the map.

\section{SEISMIC STRATIGRAPHIC BACKGROUND}

In this section, we discuss ODP results in relation to the regional and ODP seismic nomenclature, and then consider several key reflection seismic lines as an introduction to the area. Key regional reflectors (Figs. 3 and 5) are those of Willcox and Exon (1976):

$\mathrm{F}$, the unconformable top of the Triassic sedimentary sequence;

E, a Callovian-Oxfordian unconformity that lies at or near the $\mathrm{F}$ unconformity in this area and is not mappable seismically;

$\mathrm{D}$, the Valanginian unconformity at the top of the Barrow Group;

$\mathrm{C}$, the Turonian base of the Toolonga Calcilutite.

The corresponding major sequences dealt with in this paper are as follows:

Triassic, below $\mathrm{F}$ unconformity = Mungaroo Formation

Berriasian-Valanginian (F-D) = Barrow Group

Late Valanginian-Cenomanian $(\mathrm{D}-\mathrm{C})=$ Muderong, Gearle, Haycock Formations. 


\section{Sites 762,763 , and 766}

The lithologic sequences at Sites 762 and 763 are described fully by Haq, von Rad, O'Connell, et al. (1990) and Exon et al. (this volume, chapter 12) and are summarized in Figure 3. We are especially concerned with the Early Cretaceous sequences: the thick deltaic Barrow Group of Berriasian to Valanginian age and the Hauterivian-Cenomanian Winning Group. The Winning Group can be separated into three formations-the Muderong Shale, Gearle Siltstone, and Haycock Marl-that indicate increasing water depth and declining detrital input with time. The Winning Group is overlain by Turonian-Maestrichtian chalks and marls laid down in bathyal water depths.

At Site 766 (Fig. 4), located on Valanginian oceanic crust at the foot of the western scarp (Figs. 1 and 2), all sedimentary sequences are bathyal or deeper marine (Ludden, Gradstein, et al., 1990). A basal glauconitic sandstone and mudstone (lithostratigraphic Subunit 3B), of late Valanginian to Barremian age, is not represented at Sites 762 and 763. Chalks are present in the Aptian, earlier than on the plateau.

The Aptian and younger Cretaceous sequences consist mostly of chalk and calcareous ooze, with minor clays and calcareous turbidites.

\section{Seismic Profile between Sites 762 and 763}

ODP reflection seismic profile $122-6$ (Haq, von $\mathrm{Rad}$, O'Connell, et al., 1990; Boyd et al., this volume) between Sites 762 and 763 (Fig. 5) shows how seismic sequences (1-8) can be traced between the two sites. Overall, the BerriasianCenomanian sequences (3-5) thin northward, whereas the Upper Cretaceous and Paleogene sequences (6-7) thicken northward.

Seismic sequence 1 (of Haq, von Rad, O'Connell, et al., 1990) lies below reflector F. It consists of parallel-bedded reflectors and represents the fluviodeltaic Upper Triassic Mungaroo Formation, which becomes increasingly marine upward in the Vinck and Eendracht wells. Sequence 2 is apparently conformable on reflector $\mathrm{F}$ above sequence 1 , and represents the very thin, shallow marine, Upper Jurassic Dingo Claystone drilled in Vinck No. 1. In the region as a whole, the Late Jurassic Dingo Claystone was deposited toward the end of the major Late Triassic to Late Jurassic rift phase. Commonly, it is cut by those faults that cut the Mungaroo Formation, but their amplitude decreases upward (Barber, 1988; Boote and Kirk, 1989). Sequence 3 was penetrated at the ODP sites; it downlaps and onlaps reflector E to the north and west, and the prograding clinoforms represent the bottom-set and foreset beds of the early Neocomian Barrow delta, which are largely mudstone, with some turbidite sandstones toward the base. Reflector D, above sequence 3 , forms a truncated/toplap boundary in places.

Sequence 4 is parallel bedded, onlaps sequence 3 at reflector D in places (Fig. 5), and is equivalent to the transgressive shallow-marine mudstone of the Muderong Shale (Fig. 3). Sequence 5 is conformable on sequence 4 and represents the Gearle Siltstone and Haycock Marl (Figs. 3 and 5). Sequence 6 onlaps sequence 5 at reflector $C$ and consists of bathyal carbonates. The top of sequence 6 is an erosional unconformity (reflector B) separating the Cretaceous and Tertiary sequences.

\section{Regional Seismic Profiles}

Two reflection seismic profiles link Sites 762 and 763 with Site 766, across the outer plateau and continental slope. Profile 55/02 (Figs. 2 and 6) runs west-northwest from Site 763 to Site 766. On the central plateau, the bedded Triassic sequence below the unconformable reflector $\mathrm{F}$ is markedly faulted. Westward, reflector F merges into reflector V, marking the top of an inferred volcanic sequence (see discussion in "Volcanic Basement"' section). The Neocomian Barrow delta (F-D) onlaps and fills the deeps formed by faulting at the F horizon, thins westward through Site 763 , and pinches out against a high in reflector $\mathrm{V}$. West of that high is a reflectorfree sequence (V-D), $25 \mathrm{~km}$ wide and equivalent to the Barrow Group. The younger sequences generally maintain their character and thickness westward to the top of the steep volcanic continental slope, where they are thin or absent. At Site 766, reflector $\mathrm{V}$ is the top of a sequence of sills, which may represent Valanginian oceanic crust. Around Site 766, the sequences above basement have a different character from, and are physically separated from, those on the plateau and form different seismic units (Buffler et al., in press). There, only the equivalent of the late Valanginian to Cenomanian (D-C) sequence is present.

Reflection seismic profile 55/04 (Figs. 2 and 7) runs westward from Site 762 to Site 766 . It shows both similarities to and differences from profile 55/02 (Fig. 6). The change westward, from faulted Triassic sediments to inferred volcanic rocks, is still apparent, but the F reflector steps down westward by greater throws on faults, and the top of the volcanic sequence is considerably lower. The F-D (Barrow) sequence thickens westward by gaining section toward its base. The physical continuity of the characterless V-D sequence with the F-D sequence shows its equivalence. The younger sequences on the plateau are somewhat similar to those in profile $55 / 02$, except toward the outer plateau, where there is a local thickening of the D-C sequence.

Seismic profile Esso $3 \mathrm{~A}$ is on the southwestern margin of the plateau, in the southeastern corner of the study area (Fig. 8). A regional structural high lies under the uppermost slope, trending west-northwest along the margin, with its crest at about shotpoint 820 on this profile. Here, the Cretaceous and older sequences roll over toward the Cuvier Abyssal Plain to the southwest. A deep reflector, G, is probably intra-Triassic, rather than Permian as was surmised by Exon and Willcox (1978), because the Triassic exceeds $3000 \mathrm{~m}$ in thickness in the petroleum exploration wells. Reflector F marks the top of the well-bedded Triassic sequence. The Barrow delta sequence (F-D) apparently crops out on the continental slope because of erosion, and then thins slightly northward as part of one delta lobe to about shotpoint 600 , where it begins to thicken as part of another lobe. High-angled faults markedly offset reflector F and commonly terminate there; in places they persist upward to the Valanginian top of the Barrow delta (reflector D) but with much reduced throw. The younger sequences (above reflector D) are relatively thin and tend to pinch out against the marginal high at shotpoint 820 .

\section{CONSTRUCTION OF MAPS}

As a part of this study, the authors produced four maps of the southwestern Exmouth Plateau and adjacent abyssal plains: bathymetry (Fig. 2), basement structure on horizons $\mathrm{F}$ and V (Fig. 9), early Neocomian (F-D) thickness and late Neocomian magnetic lineations (Fig. 10), and mid-Cretaceous (D-C) thickness (Fig. 11). The maps were prepared after the regional seismic profiles (Fig. 2) had been interpreted, taking into account the results from Sites 762 and 763 (Haq, von Rad, O'Connell, et al., 1990) and 766 (Ludden, Gradstein, et al., 1990) and from the Esso Eendracht No. 1 and Vinck No. 1 exploration wells (at Sites 762 and 763, respectively).

The bathymetric map (Fig. 2) was constructed from available data, including that from the GEBCO $1: 1,000,000$ scale 


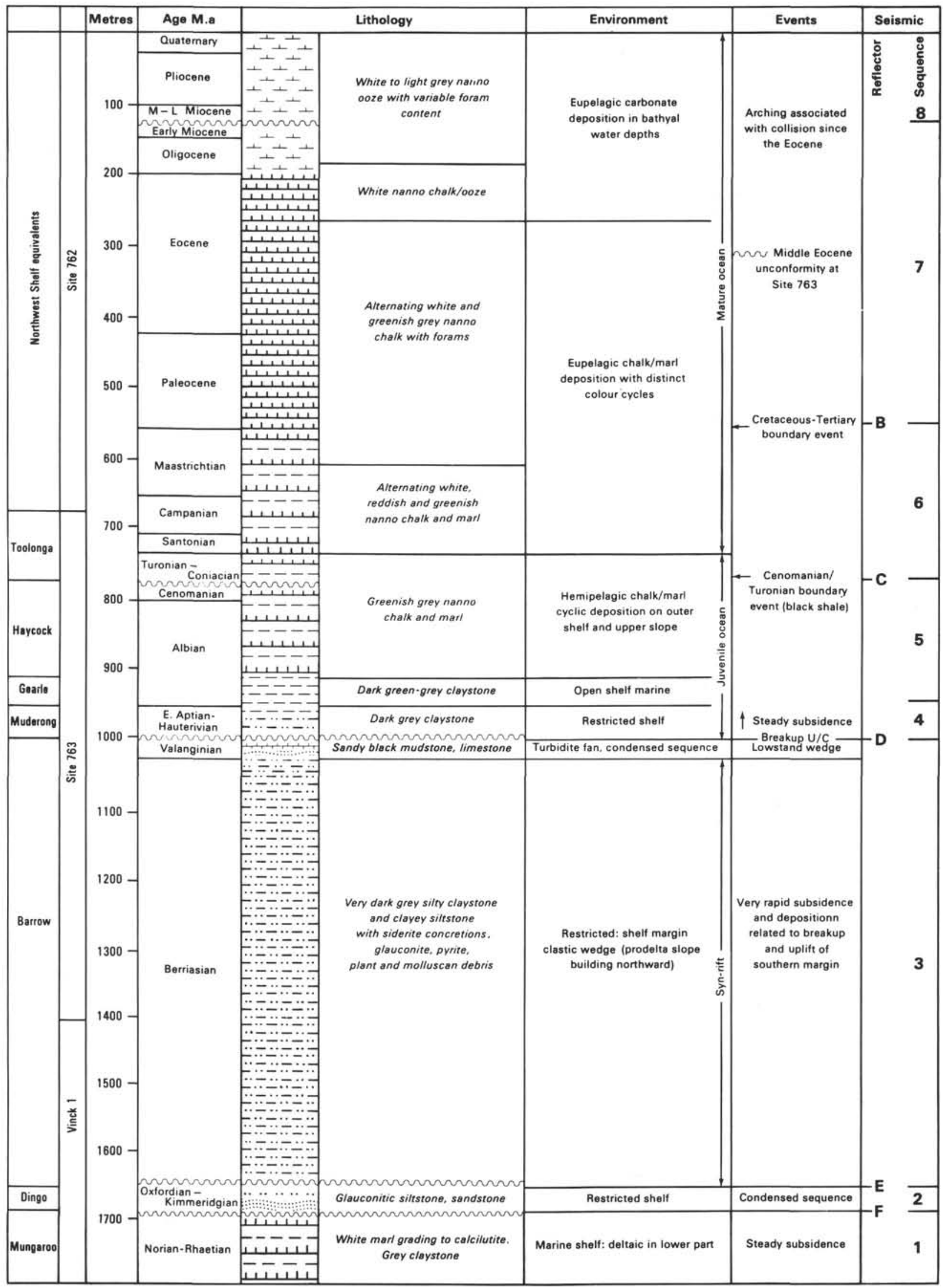

Figure 3. Composite lithologic log for Sites 762 and 763 and Esso Vinck No. 1 well. 


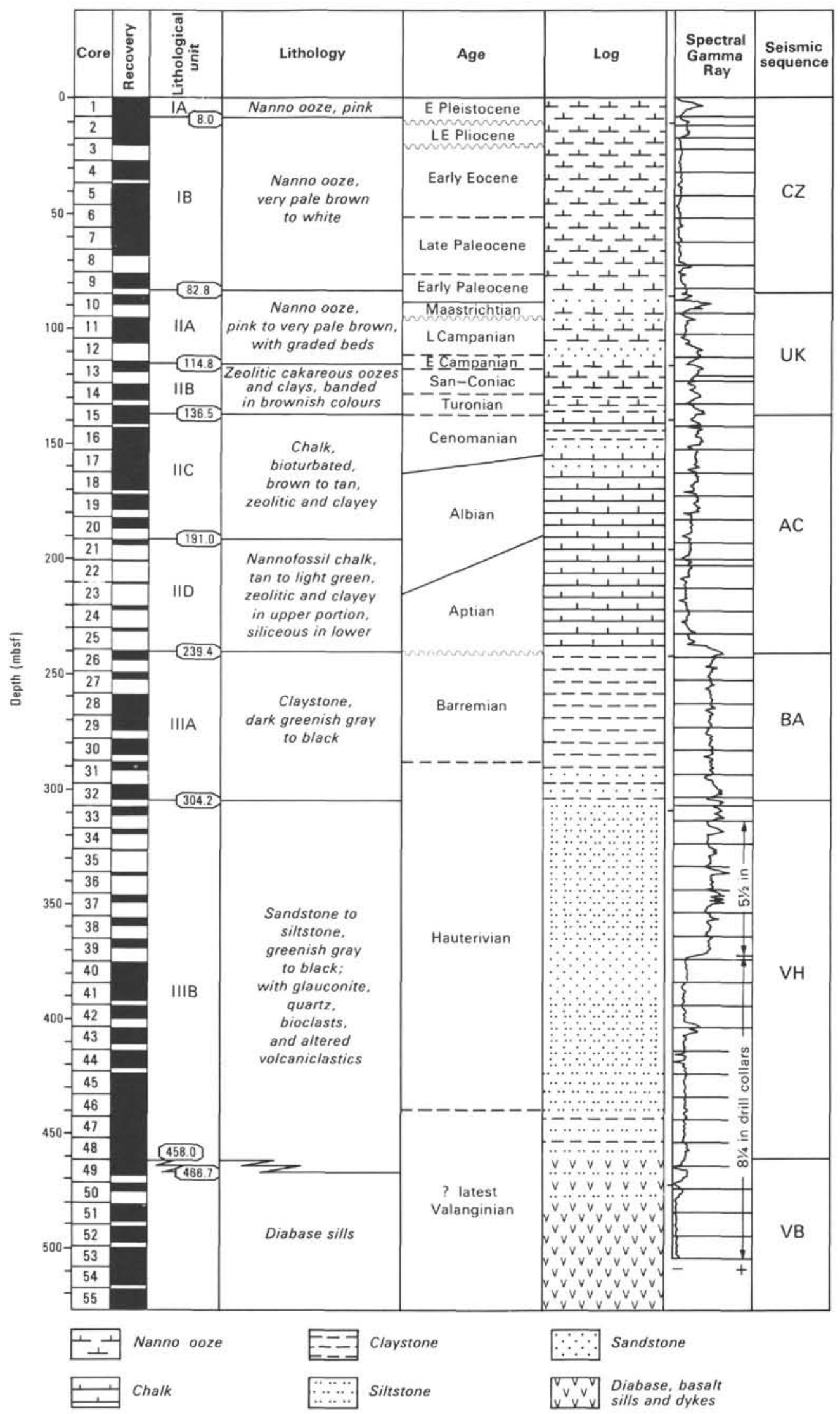

Figure 4. Lithologic log for Site 766, redrawn from Leg 123 Shipboard Scientific Party (1988). 


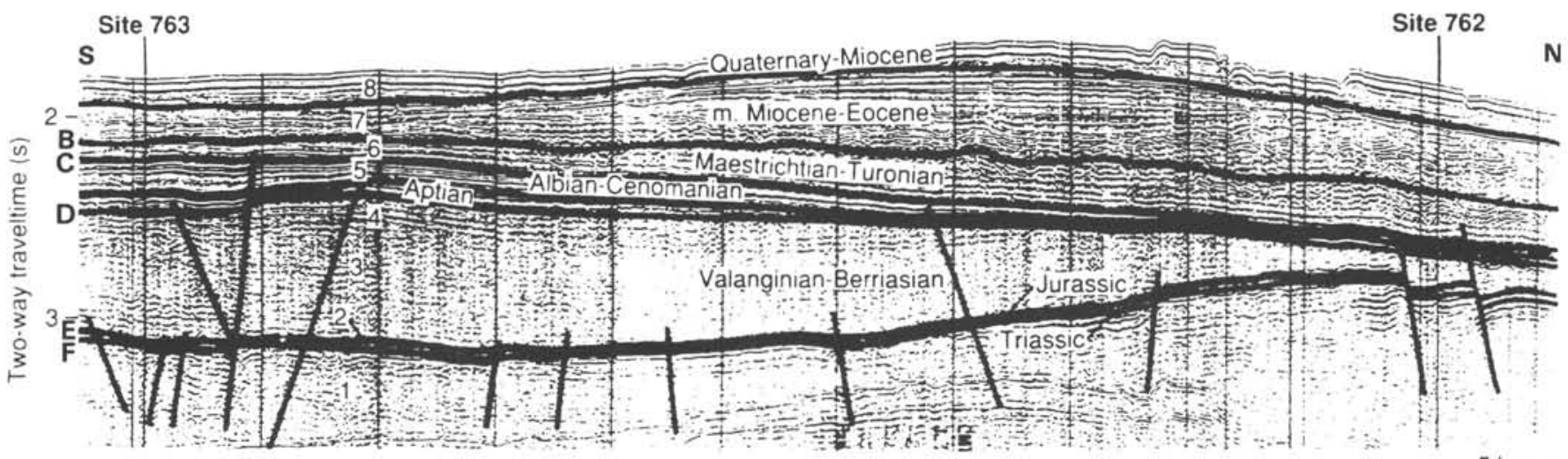

Figure 5. ODP seismic profile 122-6, between Sites 762 and 763, showing alphabetical reflector nomenclature of Willcox and Exon (1976), ODP numerical seismic sequence nomenclature, and approximate ages of seismic sequences. From Haq, von Rad, O'Connell, et al. (1990). Location in Figure 2.

sheets. Because the data grid is generally rather sparse and patchy, we contoured only every $500 \mathrm{~m}$.

The "basement" contour map, in seismic two-way traveltime (TWT) (Fig. 9), is generalized from the seismic lines. It shows the top of Upper Triassic sediments (F) in the east, of acoustic (volcanic) basement around the rim of the plateau (V), and of oceanic crust on the abyssal plains (V). Within the area of Triassic sediments, there is extensive faulting and local offsetting of the contoured surface (largely trending north to northeast), but this has been smoothed to produce the map. The "limit of Triassic sediments" is placed where, on the seismic sections, bedding can no longer be seen beneath the contoured surface (e.g., 74.0940 in Fig. 12). Three flat erosion surfaces, developed on highs of acoustic basement, are shown stippled in Figure 9.

The continent/ocean boundary (Fig. 9) is picked from the seismic sections generally at the foot of the steep continental slope. We believe the crust under the outer plateau to consist of continental rift volcanics (see "Volcanic Basement" section). The oceanic crust is basement on the abyssal plains and includes one major volcanic buildup west of Site 766 (Fig. 9). Oceanic magnetic lineations (Fullerton et al., 1989) confirm its interpretation as Neocomian oceanic crust (Fig. 10).

The Neocomian map (Fig. 10) is a composite diagram, showing the thickness (s TWT) of the early Neocomian F-D sequence on the Exmouth Plateau and the late Neocomian oceanic magnetic lineations on the abyssal plain (after Fullerton et al., 1989). The F-D sequence corresponds to the upper Neocomian Barrow Group (see "Late Jurassic to Early Cretaceous Sequence"). The oldest sediments on the abyssal plains are late Neocomian, and are not represented on this map.

The D-C "mid-Cretaceous" thickness map (Fig. 11) shows the thickness (s TWT) of sediments of Cenomanian and older age, which rest on Barrow Group sediments on the plateau and on oceanic basement on the abyssal plains (see "MidCretaceous Sequence"'). On the plateau the oldest D-C sediments identified are Hauterivian (Brenner, this volume, chapter 31), whereas on the abyssal plains they are late Valanginian.

\section{MAJOR SEISMIC UNITS}

This section describes the major seismic units in the area, starting with the Triassic and ending with the mid-Cretaceous. It deals with their general character and regional variation and their implications for geological history.

\section{Triassic Sediments (pre-F)}

The eastern part of the study area (Fig. 9) is underlain by faulted Triassic sedimentary rocks, capped by the $\mathrm{F}$ unconformity (see also Figs. 6-8). Beyond the Triassic sediments to the west is inferred volcanic basement (see following section).

In the Triassic, the western Exmouth Plateau was part of the southern margin of Tethys and the northern margin of Gondwana. It had subsided rapidly in the late Permian and into the Triassic, in response to crustal stretching and thinning (e.g., Williamson et al., 1990). There was probably an Early Triassic marine transgression, like that which deposited the Locker Shale farther east, but this has not been documented here. Exploration wells show that in the middle and Late Triassic, several thousand meters of fluviodeltaic sediments were derived from the south and east and covered the plateau; late in the Triassic, deposition was largely shallow marine. The seismic profiles show that, within the Triassic sequence, the reflecting layers are concordant and alternately of high and low amplitude. The sequence is at least $2 \mathrm{~s}$ TWT thick in most places.

During a latest Triassic to Late Jurassic period of faulting, there was little net deposition of sediments in this area, and the F unconformity developed by tilting, nondeposition, and some erosion. Seismic profiles such as those across the western margin, illustrated in Figures 6 and 7, and across the southwestern margin such as Esso 3A (Fig. 8) show that faults are mostly very steeply dipping. Detailed mapping in the central Exmouth Plateau (e.g., Wright and Wheatley, 1979) indicates that there the faults generally trend north to northeast and probably represent both normal and transtensional movements. In the profiles we have studied, faults are much more common on east-west than north-south lines, also suggesting that they have a strongly north-south orientation. Some subvertical faults trend parallel to the southwestern margin and the Cape Range Fracture Zone, that is, westnorthwest (Fig. 8). Although extensively faulted, the Triassic surface is rather regular in a regional sense (Fig. 9). In the south it is fairly flat, lying at about $3 \mathrm{~s}$ TWT, but farther north there is an overall dip to the northwest and the surface falls steadily from 3 to $4.5 \mathrm{~s}$ (Fig. 9). A major high, trending west-northwest, parallels the southwestern margin of the plateau, with its core above $3 \mathrm{~s}$; the southeastern part of the high involves Triassic sediments.

Figure 7 shows that most faults dip steeply westward and are antithetic to the bedding, which dips gently eastward 

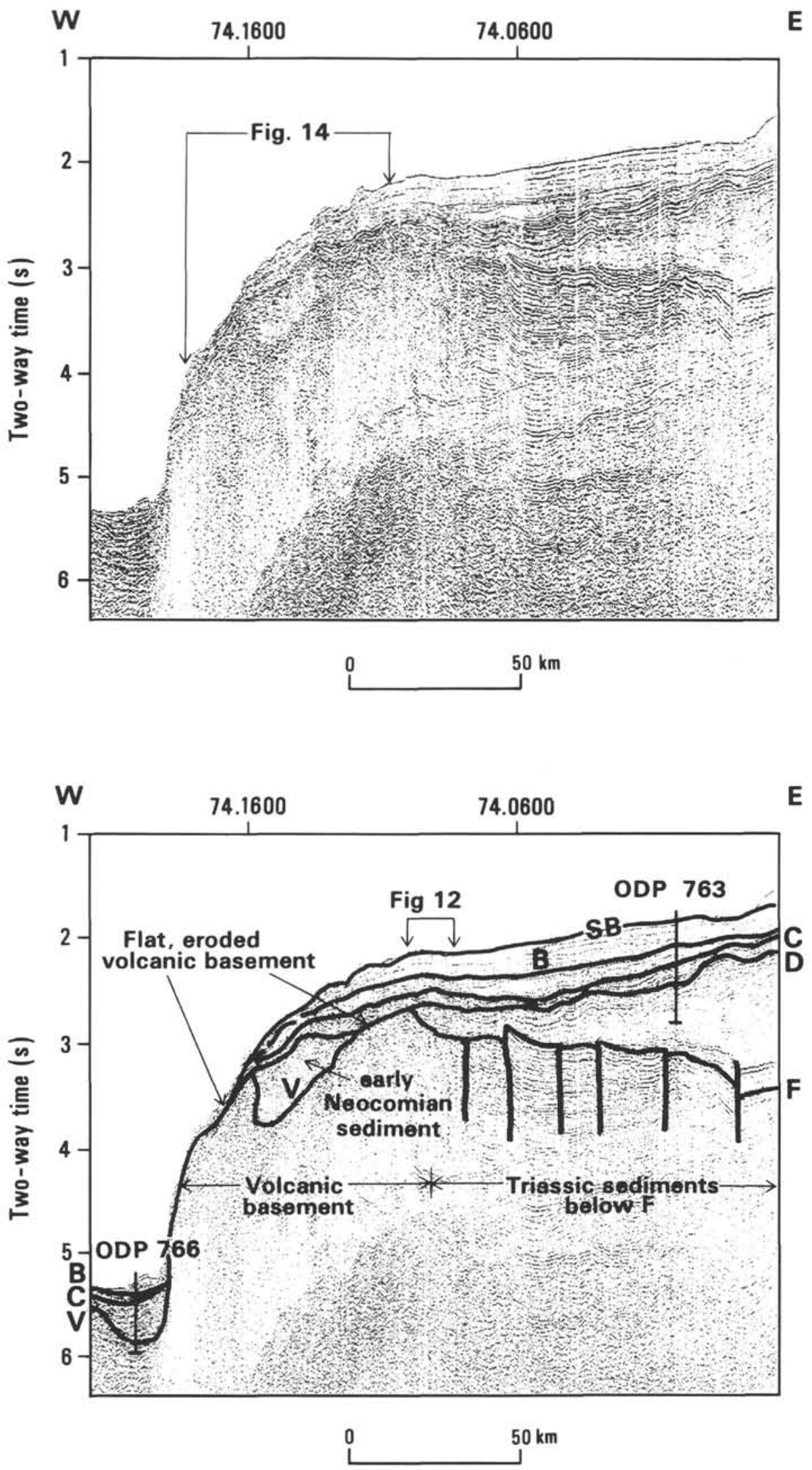

Figure 6. BMR seismic profile 55/02 and interpretation showing Sites 763 and 766 . Parts of this line are shown in more detail in Figures 12 and 14. Reflector nomenclature after Willcox and Exon (1976). SB = seabed. Location in Figure 2. 

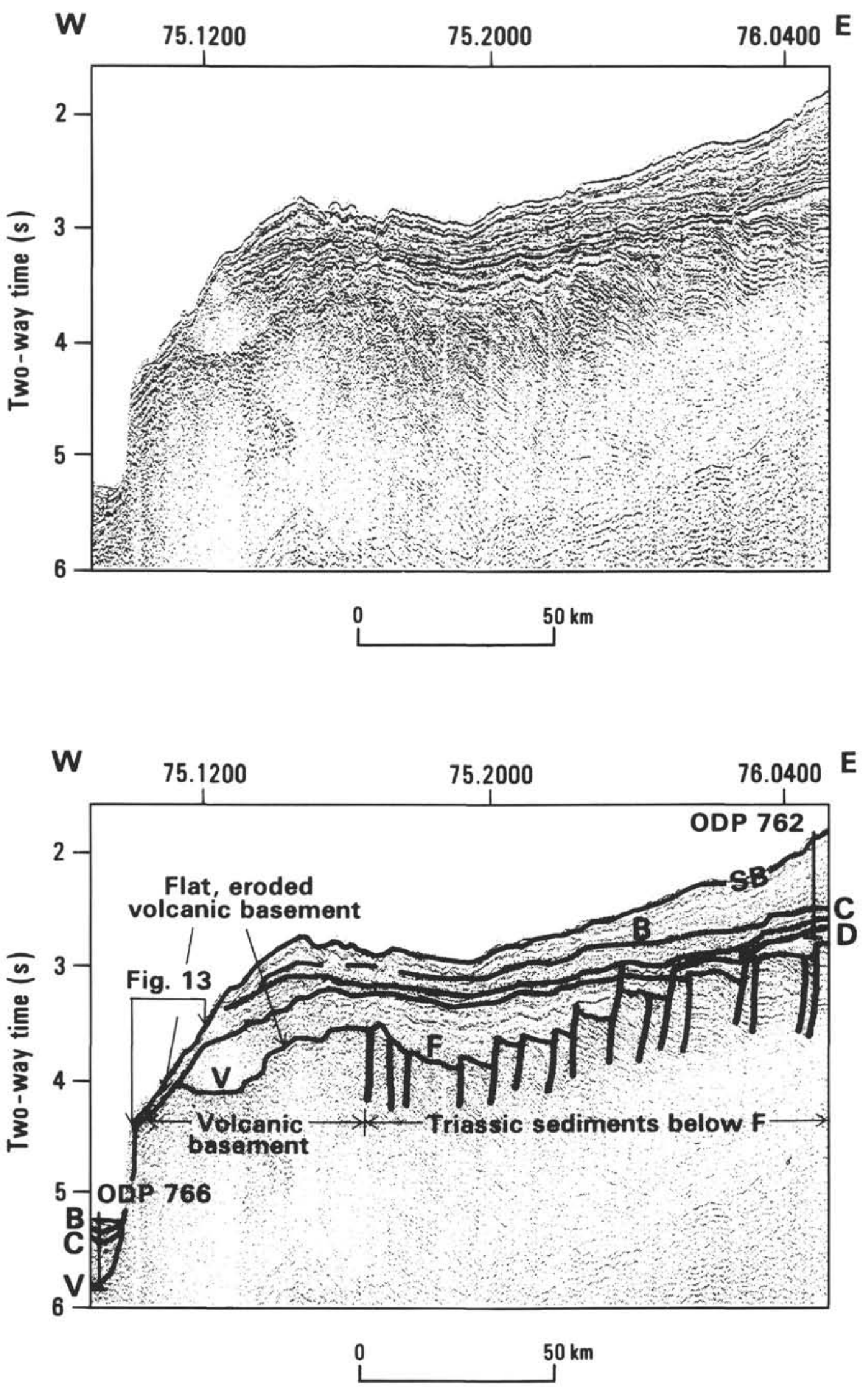

Figure 7. BMR seismic profile 55/04 and interpretation showing Sites 762 and 766 . Reflector nomenclature after Willcox and Exon (1976). More detailed part of the seismic profile is shown in Figure 13. SB = seabed. Location in Figure 2. 


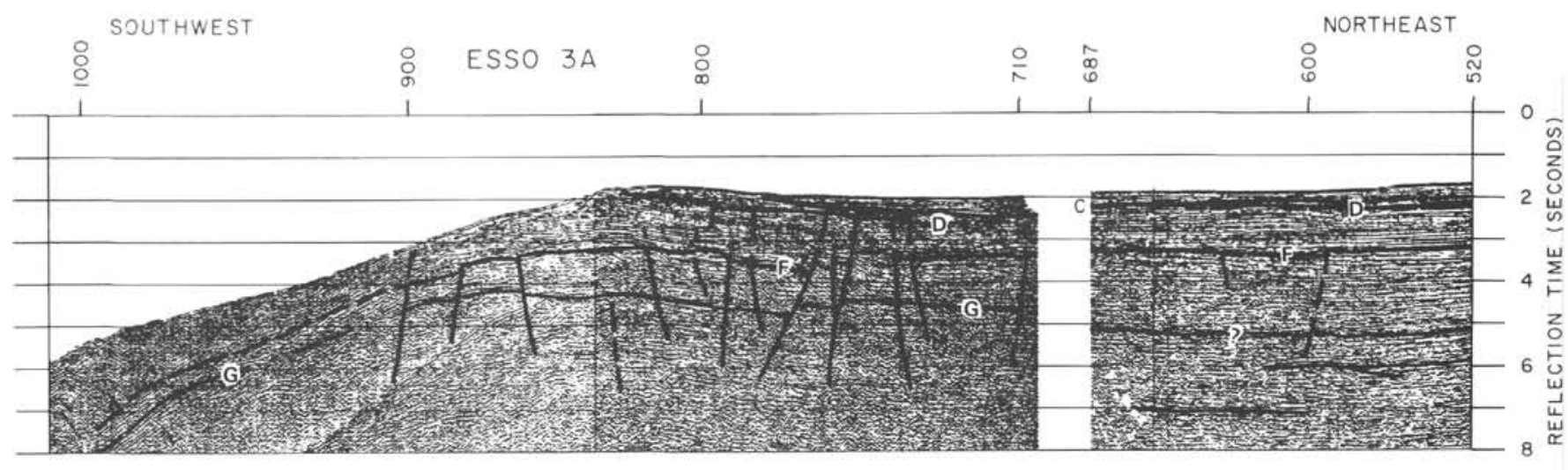

Figure 8. Regional seismic profile Esso 3A, showing structural high along the southwestern margin of the Exmouth Plateau and roll over of deep reflectors toward the Cuvier Abyssal Plain. Reflector nomenclature is generally after Willcox and Exon (1976), but G reflector is probably intra-Triassic. Location in Figure 2.

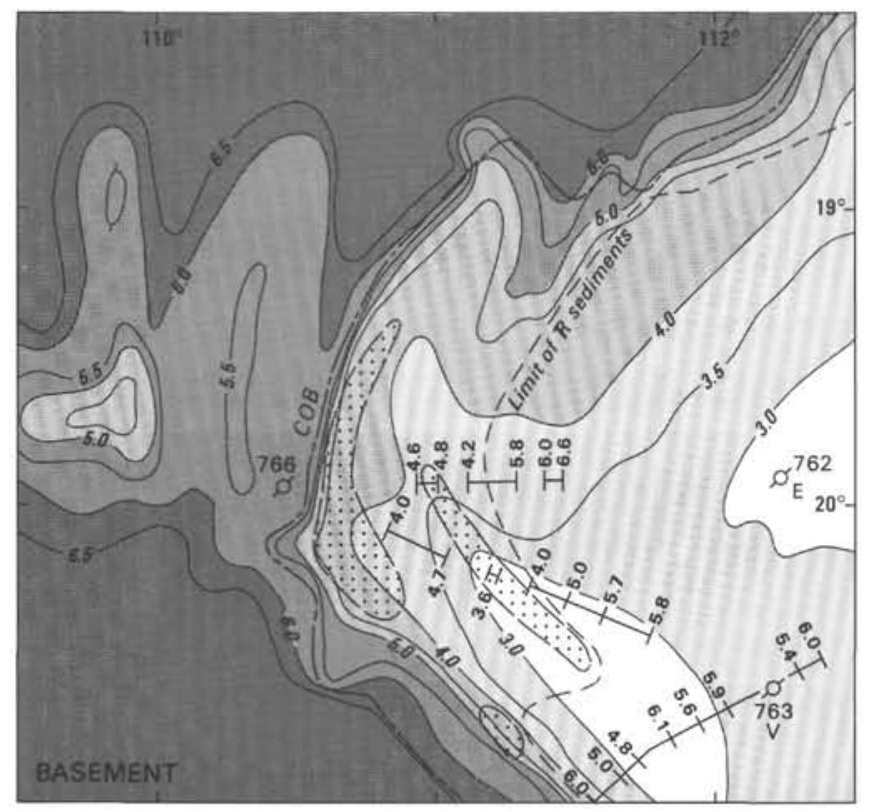

Flat erosional surface at depth

\section{$\longmapsto$ Deep reflector}

Figure 9. Map of the western Exmouth Plateau compiled from all seismic lines shown in Figure 2, contoured in seconds two-way traveltime on top of the Triassic sedimentary sequence (east), interpreted Triassic-Jurassic volcanic basement (center), and oceanic crust (west). Stippled areas are planated surfaces on top of volcanic basement, probably eroded by wave action in the Neocomian and tilted later. Also shown are depths (s TWT) to "intrabasement" reflectors, visible on BMR seismic lines 55/02, 55/04, and WACDP$\mathrm{CR}$, which probably represent Jurassic sills.

overall, and this is the common situation on the plateau (Exon and Willcox, 1978; Wright and Wheatley, 1979). The easterly dip of the sediments generally has been attributed to the westerly dip of the faulting (e.g., Willcox and Exon, 1976). However, part of the easterly dip could have been syndepositional and caused by uplift in the west related to the intrusion of rift volcanics in the Late Triassic and earliest Jurassic.

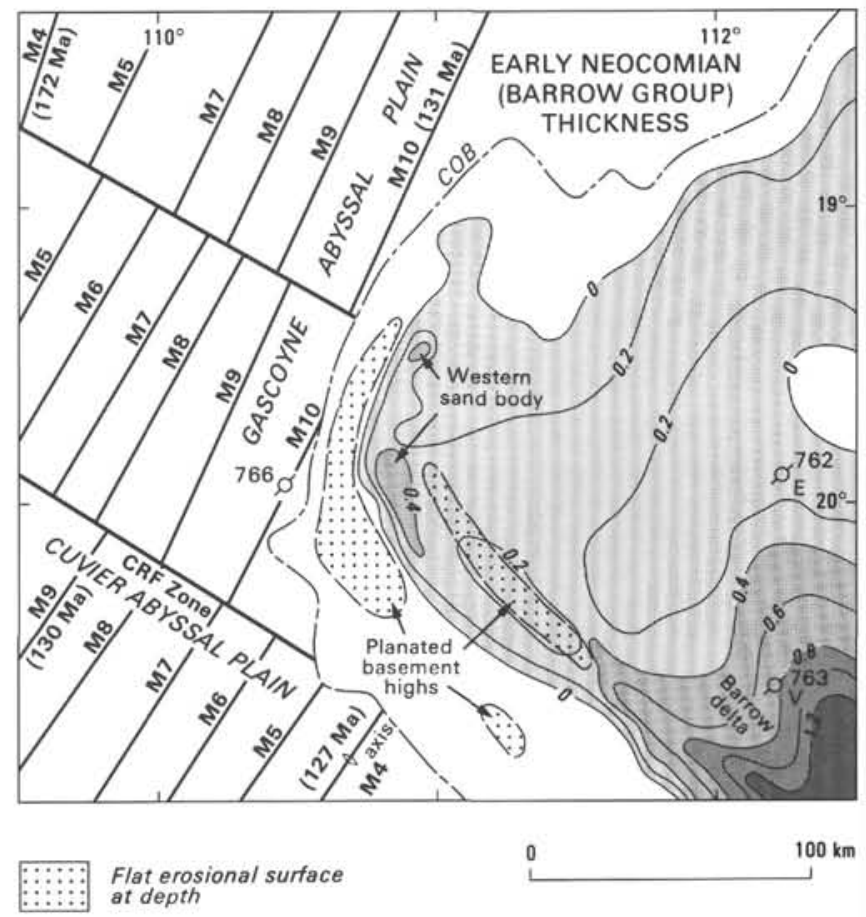

Figure 10. Map showing thickness (s TWT) of the F-D sequence, with the Berriasian-Valanginian deltaic Barrow Group in the east (which includes a thin Upper Jurassic Dingo Claystone sequence). On the western plateau an equivalent sand body ( $>0.4 \mathrm{~s}$ thick) has been derived from the western volcanic ridge. The F-D sequence is not present on the later-formed abyssal plains of late Valanginian-Hauterivian age. Magnetic anomalies after Fullerton et al. (1989) are dated using the Harland et al. (1982) time scale. CRF Zone = Cape Range Fracture Zone, which continues east-southeast to form the boundary between the Exmouth Plateau and Cuvier Abyssal Plain.

\section{Volcanic Basement}

Northwest, west, and southwest of the Triassic sedimentary sequence, a generally reflector-free body of rock forms basement to the outer western Exmouth Plateau (Fig. 9). Regional east-west seismic profiles 55/02 and 55/04 show these rocks to occur in a belt about $50-60 \mathrm{~km}$ wide, of very different seismic character to the Triassic sediment. Detailed pieces of 


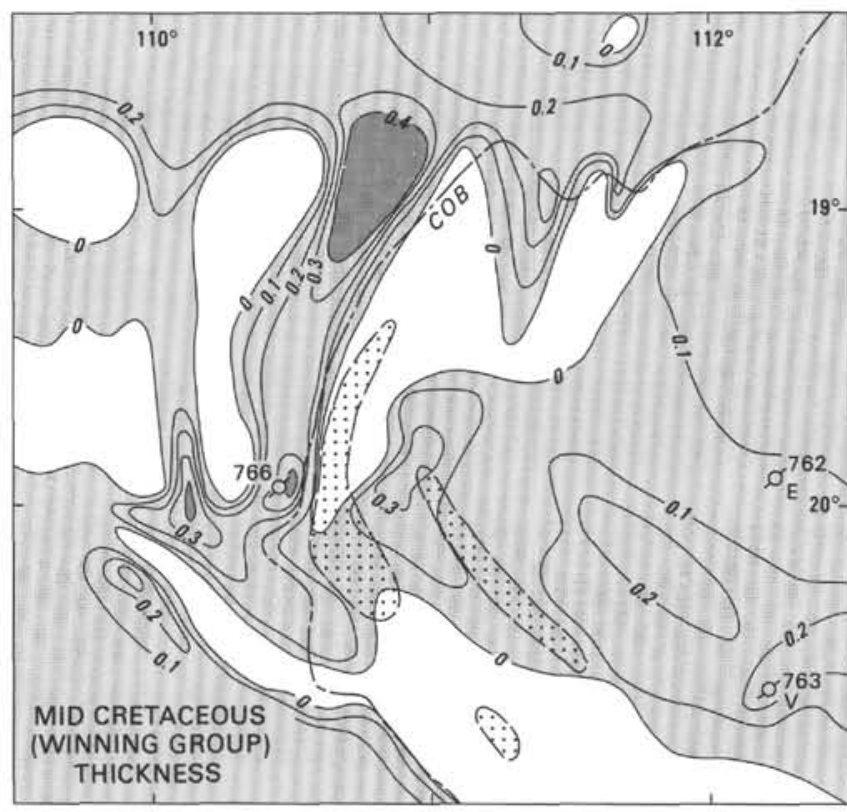

Flat erosional surface $100 \mathrm{~km}$ at depth

Figure 11. Map showing thickness (s TWT) of the D-C sequence, equivalent to the Hauterivian-Cenomanian Winning Group on the plateau. Note the locally thick sequences at the foot of the continental slope, such as that at Site 766 (upper Valanginian-Cenomanian), and the relatively thick sediment body on the westernmost plateau $(>0.3$ s), near planated basement highs (stippled) and a Neocomian sand body (Fig. 10).

profiles, such as illustrated in Figure 12, show the transition from bedded, faulted Triassic sediments to these virtually unbedded rocks, which generally have an irregular upper surface (V).

Recent dredging (BMR 96/DR-34) at a location on the scarp east of Site 766, the scarp that forms the western limit of the plateau, recovered a variety of volcanic rocks (Colwell et al., 1990). The dredge haul was taken in water depths of $3950-$ $3410 \mathrm{~m}$, very near profile $55 / 04$, and centered on $19^{\circ} 56^{\prime} \mathrm{S}$, $110^{\circ} 34^{\prime} \mathrm{S}$. The rocks recovered have been examined only as hand specimens so far, and are described as amygdaloidal basalt, veined porphyry, and ?andesite.

By analogy with the northern plateau margin, where similar rocks in a similar setting have been recovered by dredging (von Stackelberg et al., 1980; Exon and Williamson, 1988), these rocks are probably rift-related volcanic flows, sills, and dikes: trachytes, andesites, and basalts. On the northern margin their $\mathrm{K} / \mathrm{Ar}$ age is latest Triassic to earliest Jurassic. In a zone of transition on the western plateau, the Triassic sediments appear to be interbedded with the volcanics, supporting a Late Triassic age for any flows (Fig. 12). Because these volcanics have little magnetic expression on the BMR geophysical profiles, they are unlikely to be dominantly basalt.

The contours on the volcanic surface on the western plateau show that it slopes gently upward away from the Triassic sediments, and then gently downward, and finally falls away abruptly to form the main scarp of the continental slope (Fig. 9). Its elevation varies from less than $3 \mathrm{~s}$ TWT along the high near the southwestern margin to almost $6.5 \mathrm{~s}$ on the deep crustal profile WACDP-CR (southeast corner of Fig.
9), at the edge of the Cuvier Abyssal Plain. In three places, ridges of volcanic material have been planed off. The central planated ridge (Figs. 6, 7, 9, and 13) is along the axis of the basement (and bathymetric) high that trends west-northwest across the plateau for $100 \mathrm{~km}$ near the southwestern margin. The western ridge, of comparable size, forms the outermost margin of the upper plateau (Figs. 6, 7, 9, and 13). Both the central and western ridges are visible in Figures 6, 7, and 14, and are separated by a depression. The southern ridge is comparatively small and is buried in the continental slope.

\section{Late Jurassic to Earliest Cretaceous Sequences (F-D)}

During the Jurassic there was little or no deposition in this region and the F-E sequence, of Early and Middle Jurassic age, is not widely identifiable on seismic profiles. The overlying E-D sequence, generally of Late Jurassic to early Neocomian age, here is represented almost entirely by the early Neocomian Barrow Group or equivalent strata.

After the Jurassic period of little deposition, there was uplift to the south (Exon and Willcox, 1976; Veevers and Powell, 1979), and Berriasian-Valanginian sands and muds were laid down in the huge Barrow delta system (Boote and Kirk, 1989), of which the two westernmost lobes are present in this area (southeastern corner of Fig. 10). The eastern lobe trends north-northwest, and general thinning as well as prograding azimuths show that it was derived from the south and southeast (see Boyd et al., this volume, for more detail). Figure 5 shows how the Barrow Group (E-D sequence) thins northward from Site 763 to Site 762 , as part of the eastern lobe. The western lobe trends west-northwest and is shown, by our mapping and that of previous workers, also to have been derived from the south and southeast. The thickness of this eastern delta system varies from 0.2 to $1.2 \mathrm{~s}$ TWT in the area of Figure 10 (i.e., up to $1500 \mathrm{~m}$ ).

BMR seismic profile 17/062 illustrates the two distinct delta lobes, separated by a saddle at 43.0610 (Fig. 15). On this east-west profile the eastern lobe appears to have built westward, and the western lobe eastward; the two merge in the saddle. Profile WACDP-CR (location in Fig. 2) shows a movement of depocenters northeastward with time. On northsouth BMR profile 17/063 (Fig. 16) the thickest part of the western lobe of the delta is just landward of the Cuvier Abyssal Plain, so much of the delta must have come from the region that is now occupied by oceanic crust, but once was occupied by Greater India. All seismic profiles in this area show that a rather homogeneous prodelta sequence was laid down, which Sites 762 and 763 prove to be largely mud. Sporadic sands were deposited as basinal turbidites, and some of these are visible low in the seismic profiles.

In the western corner of the present-day Exmouth Plateau there are two planated ridges of volcanic basement (locations in Fig. 10). Between these northerly-trending ridges is a characterless sediment body that is continuous with the Barrow Group on seismic profile 55/04 (Figs. 6, 7, and 14) and is hence almost certainly of Neocomian age. This sediment body (Fig. 10) trends northerly and is $90 \mathrm{~km}$ long, $25 \mathrm{~km}$ wide, and has a thickness of $0.25-0.45 \mathrm{~s}$ TWT (up to $500 \mathrm{~m}$ ). It is isolated from the main body of the Barrow delta (Fig. 10), and its origin is clearly local.

Its distribution and seismic character suggest that this Neocomian sediment body, which onlaps and infills the volcanic surface, was deposited locally along the outer plateau margin as the adjacent volcanic ridges were eroded. The only agent capable of such widespread planation of volcanic material is wave action. The history of this sand body is complex, as illustrated by profile 55/02 (Fig. 14). The two planated volcanic blocks (now tilted), of the central ridge (centered on 

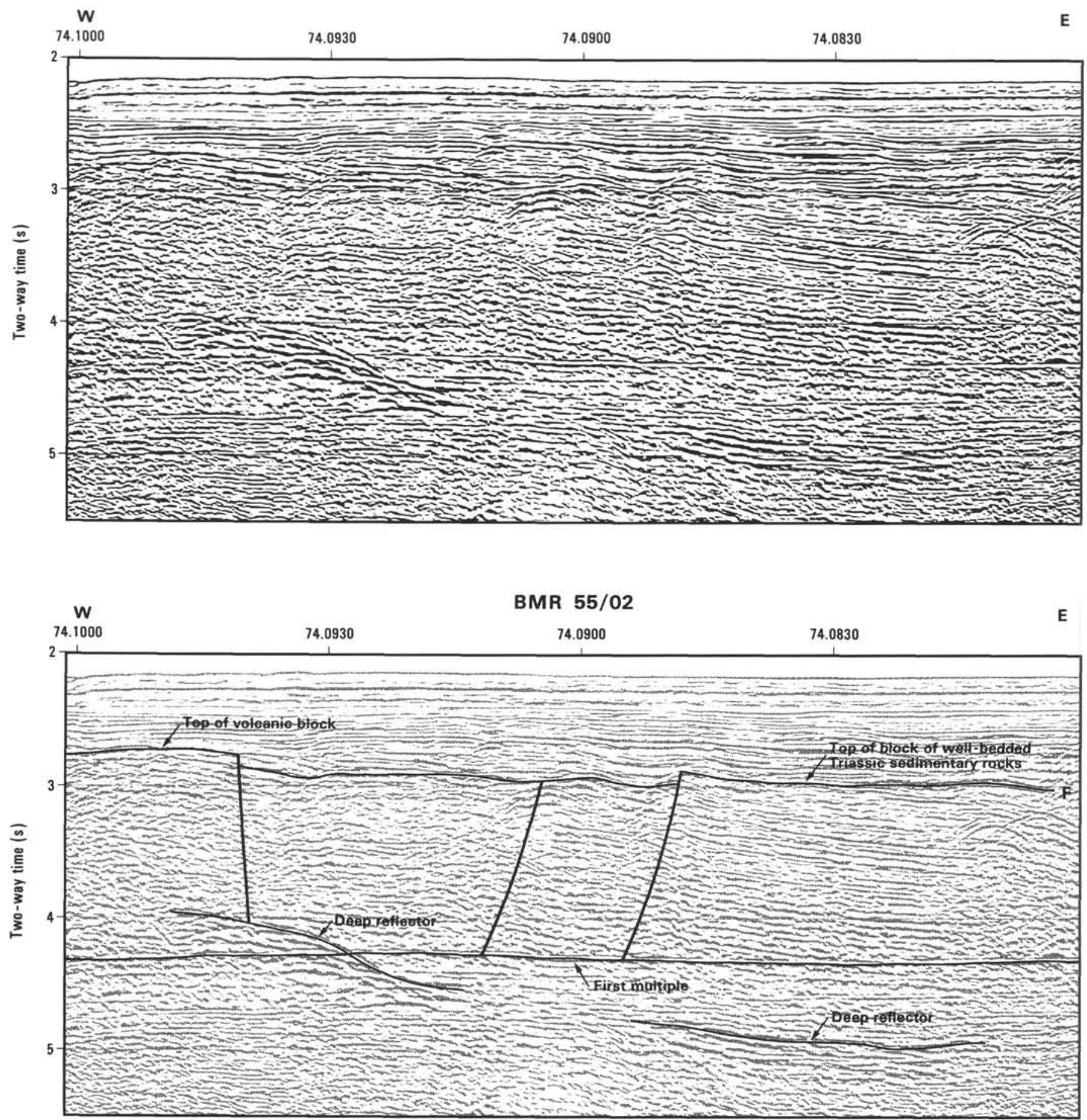

$\underbrace{5 \mathrm{~km}}$

Figure 12. Part of BMR seismic profile 55/02 across the Triassic sediment/volcanic boundary and also showing deep intrabasement reflectors (sills?) in both sedimentary and volcanic rocks. Note the transitional nature of the boundary; sedimentary rocks are interpreted as being increasingly intruded westward. Location in Figures 2 and 6. 


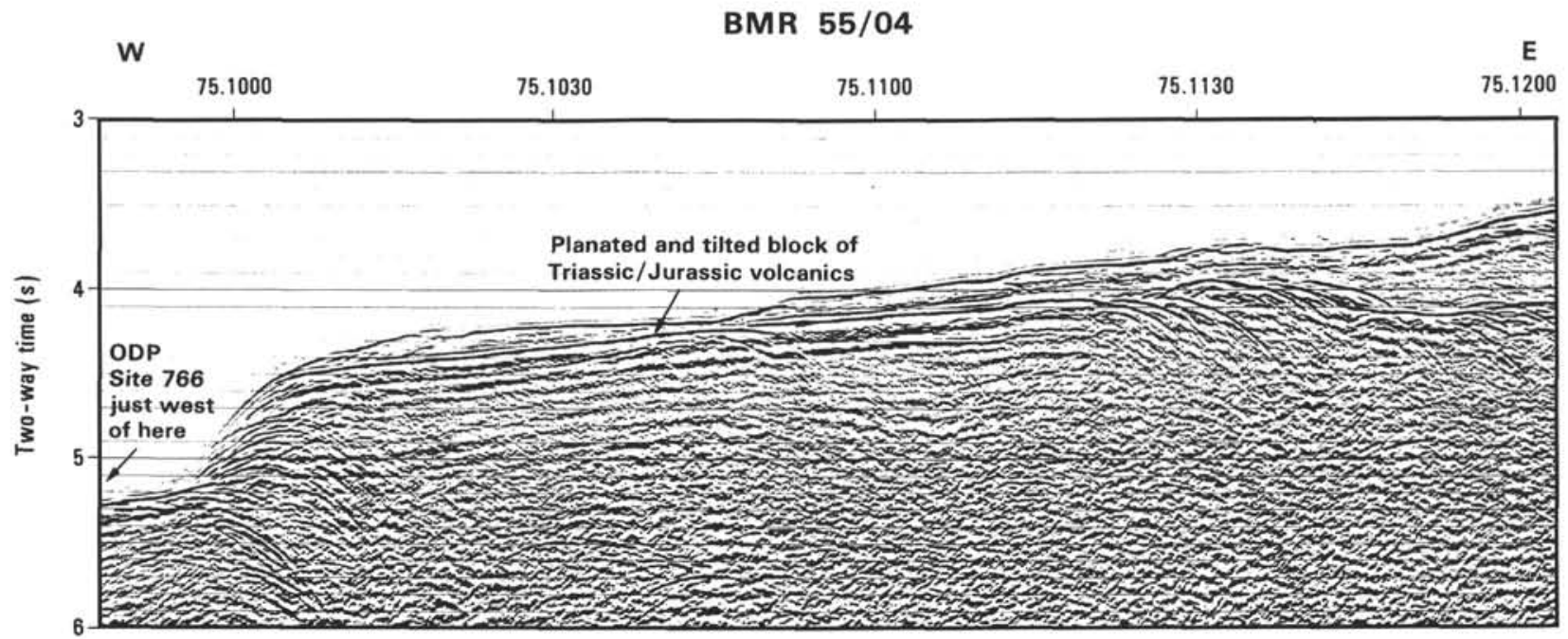

$5 \mathrm{~km}$

Figure 13. Part of BMR seismic profile 55/04 on the outermost continental slope, showing planated and tilted block, assumed to be Triassic-Jurassic volcanic rocks. Location in Figures 2 and 7.

74.1200) and the western ridge (centered on 74.1700), are separated by a depression floored by a rough volcanic surface that clearly has not been eroded.

A major mound of seismically homogeneous V-D sediment lies to the west of the central ridge (Fig. 14) and has built up above it; we assume it consists of sandstone. A wedge of V-D sediment lies to the east of the western ridge and contains high-amplitude reflectors that suggest it has prograded from the ridge and that it probably consists of interbedded sandstone and mudstone. The sediment wedge onlaps the sediment mound eastward. The seismic profile indicates that the central and western ridges were both eroded early, before much deposition occurred. The western ridge apparently stayed high throughout the early Neocomian, whereas the central ridge and intervening depression sank and were decoupled from the western ridge along the normal faults between 74.1500 and 74.1600. Most of the V-D sediment was derived from the western ridge, and probably from adjacent parts of Greater India as well. It is almost certainly volcaniclastic. The homogeneous sediment mound may possibly have been a large sediment lobe building northward between the volcanic ridges.

The volcanic rocks are probably of latest Triassic or earliest Jurassic age (see "Volcanic Basement"), but their preserved erosive products are apparently of Neocomian age. This suggests that only in the later Jurassic or Neocomian were they uplifted and brought into the zone of wave action. The obvious mechanism for such uplift is thermal doming, prior to the Valanginian breakup that is documented by the magnetic lineations on the Gascoyne and Cuvier abyssal plains (Fig. 10) and the results of Site 766 (Ludden, Gradstein, et al., 1990). The westernmost planated ridge has since developed a gentle tilt toward the abyssal plain (Figs. 6, 7, 13, and 14), presumably because of post-Neocomian subsidence of the western margin of the plateau as the oceanic crust to the west subsided.

\section{Mid-Cretaceous Sequence (D-C)}

After breakup in the late Valanginian (Fullerton et al., 1989; Ludden, Gradstein, et al., 1990) the major sources of detrital sediment to the south and west had departed, and detrital input came mostly from the east. As young oceanic crust on the adjacent abyssal plains cooled it subsided, and the whole plateau subsided with it, eventually reaching the present-day water depths. In the Early Cretaceous, detrital sedimentation gave way to that of bathyal carbonates on the plateau (Fig. 3), and by the Late Cretaceous the dominant sediments were pelagic carbonates. On the abyssal plains, after an initial burst of bathyal marine detrital sedimentation in the late Neocomian, sedimentation was dominated by pelagic carbonates, abyssal clays, and turbidites.

The mid-Cretaceous map (Fig. 11) shows the thickness (s TWT) of the shallow to bathyal marine Hauterivian-Cenomanian Winning Group (D-C sequence) on the plateau (Sites 762 and 763, seismic sequences 4 and 5; Fig. 3) and the postbreakup late Valanginian to Cenomanian sequence on the abyssal plains (Site 766 seismic sequences VH, BA, and AC; Fig. 4). This sequence is generally thin $(<0.2 \mathrm{~s})$ on the western plateau, with gradual lateral changes in thickness. Exon and Willcox (1980) showed that there is a major depocenter farther east ( $150 \mathrm{~km}$ west of Barrow Island) that is more than $1200 \mathrm{~m}$ thick. They described the D-C sequence as generally acoustically semitransparent. However, on the central plateau (Erskine and Vail, 1988; Boyd et al., this volume) the sequence consists of interbedded low- and high-amplitude reflectors. This is also the case in our study area (Fig. 14). There is a locally thick section (0.2-0.4 s TWT), in the form of an easterly prograding ridge, lying near the basement ridges on the western plateau and to the east of the thickest part of the sediment body, that is equivalent to the Barrow Group (compare Figs. 10 and 11). This may well consist of volcaniclastic sandstone and siltstone reworked from the underlying E-D sequence.

On the adjacent oceanic crust, the D-C sequence is thickest (up to $0.45 \mathrm{~s}$ ) in local depocenters near the plateau, such as that near Site 766 (Fig. 11). Grain-flow sand deposits were laid down near the base of the continental slope, such as the upper Valanginian to Hauterivian wedge (VH seismic sequence) of glauconitic sandstone and siltstone at Site 766 (Fig. 4). These were especially concentrated in local depocenters related to canyons and depressions (Fig. 11) and may be equivalents of the easterly prograding wedge on the western plateau. At Site 

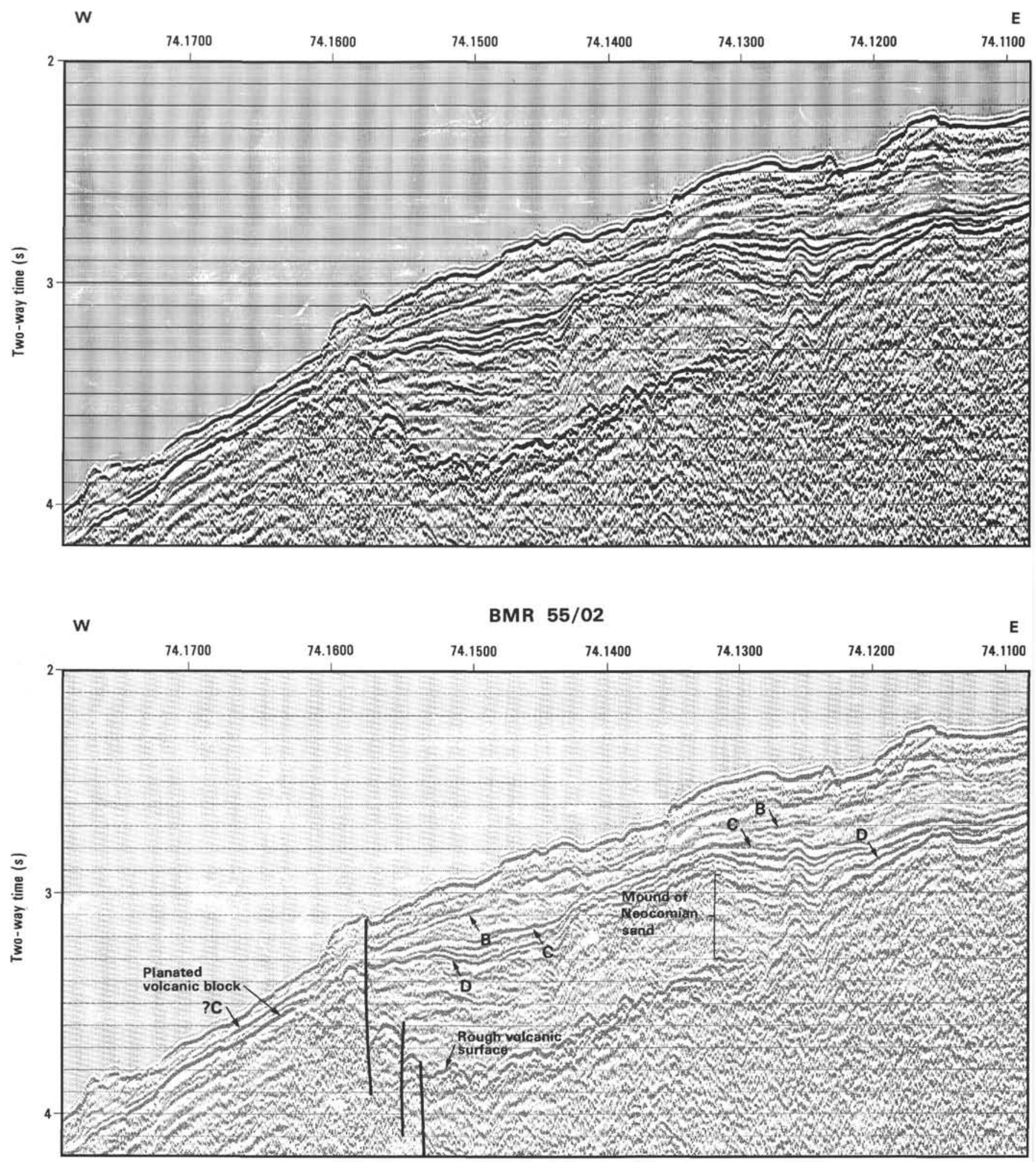

$10 \mathrm{~km}$

Figure 14. Part of BMR seismic profile 55/02, showing both the planated and rough Triassic-Jurassic volcanic basement and the thick lens of sediment below the D horizon and above basement. The sediment lens is interpreted as a lower Neocomian body (Barrow equivalent), derived from local basement highs before the Hauterivian breakup. The western part of the lens appears to have been derived from the western high after faulting lowered the eastern area. Location in Figures 2 and 6. 


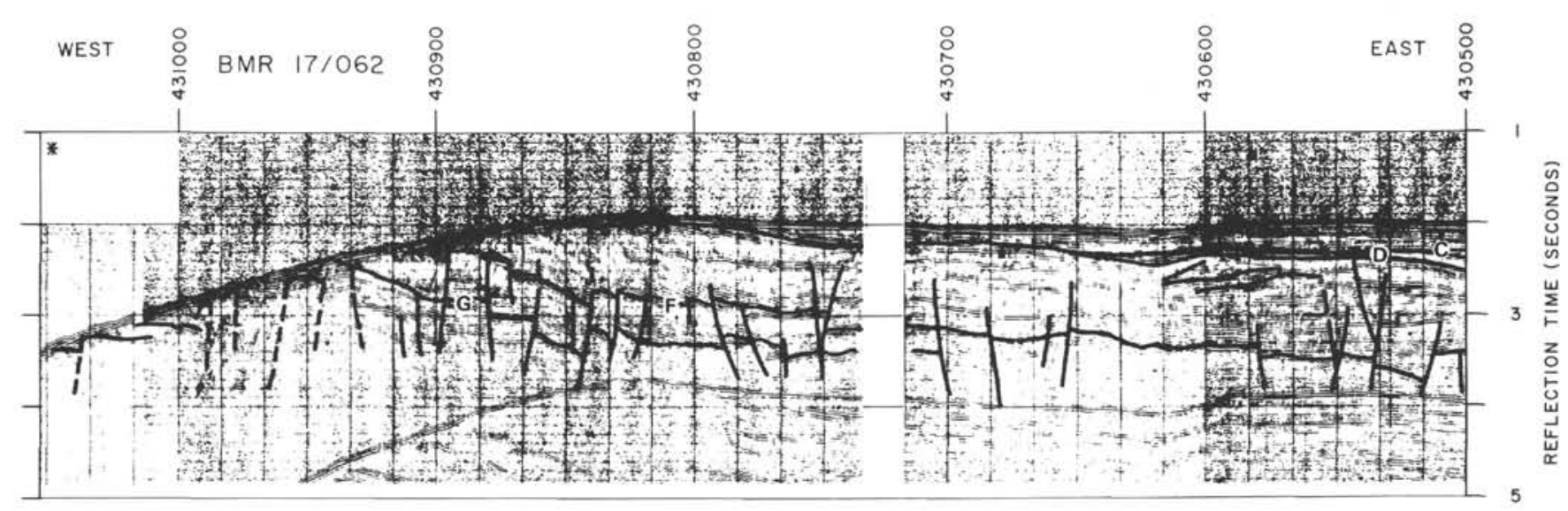

Figure 15. Part of east-west BMR seismic profile 17/062, showing the thick Berriasian-Valanginian Barrow delta (F-D), with lobes prograding from two directions (it has a component to the northeast in the west and one to the northwest in the east). Location in Figure 2.

766 the glauconitic sandstone and siltstone wedge of the $\mathrm{VH}$ seismic sequence consists of shallow-water material, derived from local shallow shelf areas and deposited in a deeper water rift basin. It is overlain by Barremian glauconitic claystone, which is overlain in turn by Aptian to Cenomanian chalks (AC seismic sequence).

Away from such depocenters near the plateau, at locations such as that of Site 261 on the Cuvier Abyssal Plain (Veevers, Heirtzler, et al., 1974), the D-C sequence deposited on basement was dominantly abyssal clay. This sequence is seismically transparent, less than $0.2 \mathrm{~s}$ thick, and contrasts strongly to the overlying well-bedded Upper Cretaceous and Cenozoic pelagic sediments and carbonate turbidites.

On the central plateau, Hauterivian to Aptian claystones derived from the east were deposited unconformably on the Barrow delta as the transgressive Muderong Shale (Fig. 3). As the water deepened in the late Aptian, detrital sediment prograded from the east (Boyd et al., this volume) and was deposited as greenish gray mudstone of the Gearle Siltstone. In Albian and Cenomanian times, there was cyclic sedimentation of hemipelagic chalk and marl of the Haycock Marl, the youngest unit of the Winning Group. Following a brief period of anoxic noncalcareous sedimentation at the Cenomanian/Turonian boundary, pelagic carbonate sedimentation dominated until the present day. The base of these carbonates forms the $\mathrm{C}$ reflector, which underlies the Toolonga Calcilutite.

\section{INTRABASEMENT REFLECTORS}

Anomalous deep reflectors occur in seismic profiles in both Triassic sedimentary rocks and the volcanic basement sequence. In some cases they cut across the bedding in the Triassic sediments. They range in subsea depth from 4 to 6.6 s TWT and generally deepen toward the center of the plateau. Depths along several seismic profiles are shown in Figure 9.

Typical examples are present in the high-quality seismic profiles 55/02 and 55/04 (e.g., Fig. 12). Such reflectors are present also in wide-angle common depth profiles recorded across the Exmouth Plateau during two-ship studies of deep crustal structure, as reported by Mutter et al. (1989) and Williamson et al. (1990), who concentrated on those reflectors that they regarded as pre-Triassic mid-crustal detachments. The detachments vary from seaward dipping, to flat lying, to landward dipping, depending on their locations.

The typical east-west profile, 55/02 (Fig. 12), shows deep reflectors within the volcanic basement in the west and the Triassic sediments in the east. Overall (Fig. 9), depths vary from 3.6 to $5.8 \mathrm{~s}$ TWT. On the full-scale version of $55 / 02$, a deep reflector is visible within volcanic basement as a continuous, eastward-dipping reflector $13 \mathrm{~km}$ across; farther east such reflectors are discontinuous and roughly flat lying. Farther east again, at the transition between volcanic basement and Triassic sediments (Fig. 12), the reflectors remain discontinuous but dip eastward, increasing in depth from 4.0 (74.0945) to $5.1 \mathrm{~s}(74.0820)$. Whether the reflectors are within structureless volcanics or stratified sediments makes no difference to their seismic character. Within the Triassic sedimentary sequence, both conformable and slightly cross-cutting discontinuous reflectors are present as deep as $6.0 \mathrm{~s}$. On seismic profile WACDP-CR (Figs. 2 and 9) similar deep reflectors are discontinuous and at various depths from 4.8 to $6.1 \mathrm{~s}$. In general, they tend to rise southwestward toward the marginal high along the southwest margin of the plateau, and then roll over toward the abyssal plain.

The relationships of most of these intrabasement reflectors to the host rocks (concordant to markedly cross-cutting) and their high seismic reflectivity strongly suggest that they are intrusive sills. Similar reflectors seen on industry seismic profiles have been identified by industry geoscientists as intrusions. Barber (1988) reported anomalous, very high vitrinite reflectance values from Triassic sediments in the Resolution No. 1 and Zeepaard No. 1 wells from the southeastern Exmouth Plateau (location in Fig. 1). He regarded these high values as clear evidence of the proximity of intrusions, and referred to the Yardie East No. 1 well southwest of Exmouth (Fig. 1), which has high vitrinite reflectance values clearly associated with drilled intrusions.

Assuming the reflectors represent intrusions, the next questions are What is their composition? and How old are they? Their composition is a matter of speculation, although their wide extent suggests a fluid magma of basic or intermediate character. Because they intrude Upper Triassic rocks, but not the lowermost Cretaceous Barrow Group, they are probably Jurassic in age and associated with the rifting events of Early to Late Jurassic age.

\section{SEDIMENTARY AND TECTONIC IMPLICATIONS}

This study has provided a number of new ideas about the western plateau and modified some old ideas, as outlined in the following.

1. Reflector-free acoustic basement along the outer Exmouth Plateau (e.g., Fig. 14), which has a rough and irregular 
S

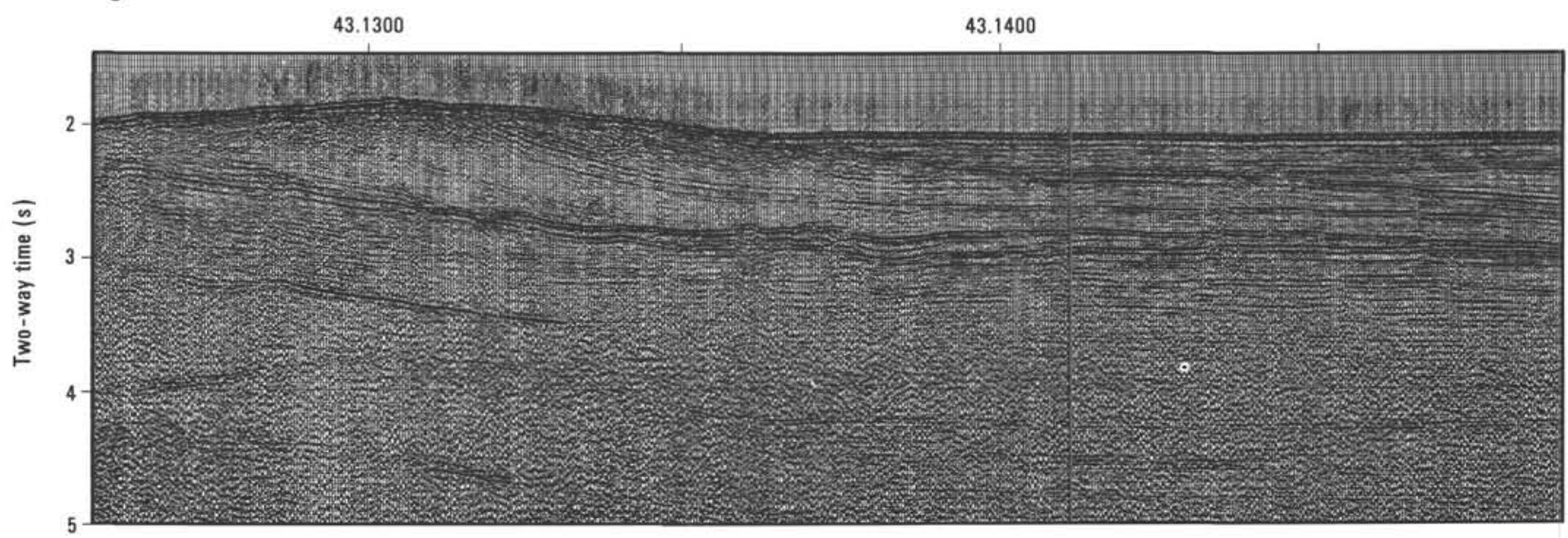

s

BMR 17/063

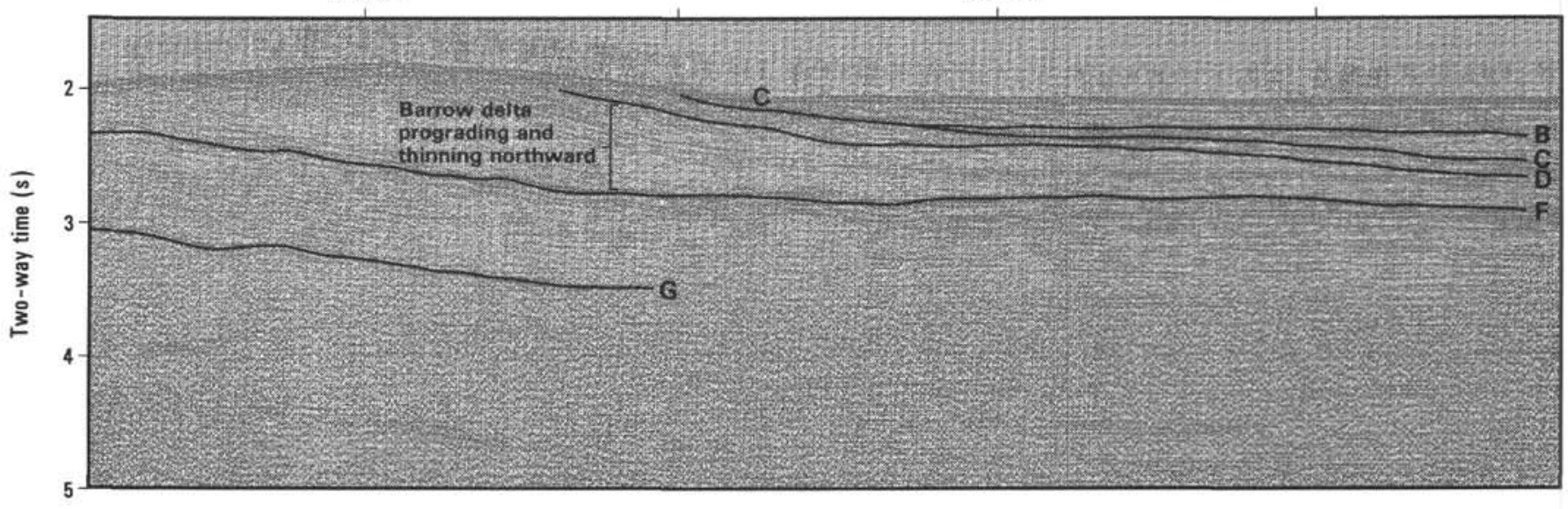

Figure 16. Part of north-south BMR seismic profile 17/063, showing prograding and marked thinning of the Berriasian-Valanginian Barrow delta (F-D) northward. This is strong evidence of a southerly source. Note onlap of C to seabed sequences onto the delta. Location in Figure 2.

top that is approximately level with the F unconformity, forms a transition zone between Triassic sediments and the continent/ocean boundary (Fig. 9). Seismic and dredging evidence indicate that this acoustic basement consists of volcanic rocks intruded and extruded during the Triassic/Jurassic phases of rifting that are characteristic of the Exmouth Plateau. Volcanism was concentrated particularly along the lines of weakness between the plateau and Greater India, which failed during later breakup. Seismic profiles show the boundary with the Triassic sediments to be transitional (Fig. 12), indicating some contemporaneity between the deposition of Triassic sediments and emplacement of volcanic rocks.

The volcanic basement, by analogy with the Wombat Plateau to the north (von Stackelberg et al., 1980) and the Scott Plateau to the northeast (Stagg and Exon, 1981), is probably of latest Triassic or earliest Jurassic age. It may consist largely of intermediate rocks, by analogy and also because of its lack of a strong magnetic signature. Over much of the western plateau volcanic basement is about $50 \mathrm{~km}$ wide (Fig. 9), but it is thinner in the north (see also Mutter et al.,
1989), where more of it was apparently removed with Greater India during breakup.

According to Williamson et al. (1990), the continental crust of the Exmouth Plateau was thinned to less than $50 \%$ of its original thickness during Permo-Carboniferous rifting. According to White et al. (1987), such thinning leads to partial melting by decompression of the asthenosphere as it upwells passively beneath the rift. Emplacement of a thick igneous section follows at depth and of basaltic seaward-dipping reflector sequences at the surface, and the volcanic margin thus formed near a hot spot remains close to sea level during the rift stage.

We have such a volcanic margin on the western Exmouth Plateau, with underplating interpreted by Mutter et al. (1989) and Williamson et al. (1990) at about $10 \mathrm{~s}$ TWT. The volcanic sequence on the western margin is generally lacking in acoustic character, but some vague evidence of seaward-dipping reflectors can be seen on the outer end of profile 55/02 (Fig. 14). If the White et al. (1987) model is correct, and if our assumption of a Triassic/Jurassic age for the volcanics is also 
correct, it seems that the dating by Williamson et al. (1990) of the rifting as Permo-Carboniferous is too old, and PermoTriassic is a better date. We also consider that the bulk composition of the rift volcanic rocks on the western Exmouth Plateau is more likely andesitic than basaltic, but no doubt that can be accommodated in the model.

Later uplift and erosion of volcanic basement, in the latest Jurassic or earliest Cretaceous, was probably the result of renewed thermal doming, and provides the source of sediments for the western sediment bodies that are separate from the Barrow Group. After the Neocomian breakup, parts of the basement were tilted down, as the oceanic basalts cooled, subsided, and depressed the outer plateau margin (e.g., Figs. 13 and 14).

2. Intrabasement reflectors are visible on deeper penetration seismic profiles. Some of these reflectors on the plateau are believed to be detachments related to Permo-Triassic or Carboniferous-Permian stretching and thinning of continental crust (Mutter et al., 1989; Williamson et al., 1990). However, the best developed intrabasement reflectors in the western plateau (e.g., Fig. 12) are discontinuous and appear to represent high-density intrusions, which may or may not coincide with detachments. They occur low in the Triassic sedimentary section and generally higher in the volcanic basement, with an overall dip landward. They have not been seen within the overlying Cretaceous sedimentary rocks. They have not been sampled, so their character and origin remain a matter of speculation. It is possible that they include the magnetic intrusive bodies that Veevers et al. (1985, fig. 10) modelled to produce the known magnetic anomalies on the outer continental margin on BMR profile $17 / 68$, which corresponds in position to profile 55/04 (Fig. 2). The distribution of the bodies, as seen in seismic profiles, indicates a post-Triassic and preCretaceous age, and they probably were intruded by partial melting caused by decompression of upwelling asthenosphere, at a late stage of rifting that culminated in doming before final breakup. We postulate that they are of Middle or Late Jurassic age.

3. The shear zone of the Cape Range Fracture Zone forms the southwestern limit of the Exmouth Plateau against the Cuvier Abyssal Plain and can be traced westward onto oceanic crust (Fig. 10). The magnetic anomalies (Fullerton et al., 1989), in conjunction with results from Site 766 (Ludden, Gradstein, et al., 1990), indicate that this part of Gondwana broke up in the late Valanginian, so that was when major shear movements started on the Cape Range Fracture Zone. A series of schematic cross sections across the Cape Range Fracture Zone and its successor, the southwestern margin, (Fig. 17) help illustrate how we consider these features may have developed. The cross sections have been constructed using real seismic profiles and our knowledge of geological events.

Thermal uplift of the southwestern margin in the Neocomian, before Greater India moved past along the Cape Range Fracture Zone, must have formed the regional high that is still evident in the seismic profiles (e.g., Figs. 8, 15, and 17). More than $1000 \mathrm{~m}$ of uplift is still preserved on the Triassic surface (Exon et al., 1982). Veevers and Powell (1979) compared the Cape Range Fracture Zone with the modern Levant Transform in the Middle East, where there is transtensional uplift of up to $2000 \mathrm{~m}$. Scrutton (1979), in his review of sheared margins, suggested several uplift mechanisms-upwelling of hot asthenosphere, frictional heating during compressional wrench movements, and heating by the passing spreading axis. Exon et al. (1982) indicated that all these mechanisms could well apply here, but we favor upwelling of hot asthenosphere as the major mechanism.
Upwelling of asthenosphere along the Cape Range Fracture Zone would have formed basic bodies, some of which may be sills that give rise to the intrabasement reflectors described previously. Large basic bodies could have buttressed the marginal high at depth and prevented later differential subsidence of much of the plateau margin as the basalts of the Cuvier Abyssal Plain cooled. However, there was major depression of the outermost margin along margin-parallel faults as the abyssal plain sank, giving rise to the present anticlinorium along the margin (Fig. 17).

4. The Barrow delta of the southern Exmouth Plateau, and of the Barrow sub-basin of the Northwest Shelf, is well developed in the southeastern part of our area of study (Fig. 10). Prodelta muds were drilled at Sites 762 and 763, where palynological analysis shows that the Barrow delta contains four spore subzones (after Helby et al., 1987), with the Egmontodinium torynum Zone at the top and the Cassiculosphaeridia delicata Subzone low in the delta (Brenner, this volume, chapter 31 ). In the Vinck No. 1 well, which penetrated the complete Barrow delta, the lowest subzone was Kalyptea wisemaniae (R. Helby, pers. comm., 1990). Hence, in stratigraphic terms the entire Barrow delta, up to $2000 \mathrm{~m}$ thick and $300 \mathrm{~km}$ wide, was laid down from earliest Berriasian to earliest Valanginian, about $6 \mathrm{~m} . \mathrm{y}$. Assuming an average thickness of the Barrow delta of $1200 \mathrm{~m}$, this means that depositional rates were almost $200 \mathrm{~m} / \mathrm{m}$.y., or $20 \mathrm{~cm} / 1000 \mathrm{yr}$.

The other palynological evidence of importance is that the deltaic sediments contain abundant reworked palynomorphs (R. Helby, pers. comm., 1990; W. Brenner, pers. comm., 1990 , cited in Exon et al., this volume, chapter 12). There is continuous reworking of Permian forms and sporadic reworking of Triassic and Late Jurassic forms, indicating that sedimentary rocks of these ages were major sources for the Barrow delta. Sedimentological evidence (Exon et al., this volume, chapter 12) showed that, apart from preexisting sedimentary rocks, there was a reworked volcanic component, probably derived from erosion of the Triassic-Jurassic rift volcanics concentrated along the zone of breakup.

It has long been realized that much of the delta came from the south (Willcox and Exon, 1976; Veevers and Powell, 1979). This is clearly demonstrated by seismic profiles (Figs. 8,15 , and 16) that show the delta to have built northward from the Cape Range Fracture Zone. Veevers and Powell (1979) concluded that derivation of the delta was from two sources: rocks thermally uplifted above the Cape Range Fracture Zone to the south (rather than Greater India) and the Pilbara Block to the east. The short-lived period of uplift and erosion of the Cape Range Fracture Zone is now tightly constrained as Berriasian to Valanginian by the age of the delta. We present a model of the uplift along the Cape Range Fracture Zone and the associated erosion and deposition in Figure 17. The truncation of the Barrow Group, apparent in seismic profiles such as $17 / 062$ (Fig. 15), probably occurred largely at the latest stages of uplift and early stages of marginal collapse, in the Valanginian and Hauterivian.

The volume of the delta probably exceeds the volume of Jurassic, Triassic, and Permian sediments that could have been eroded from the continually rising Cape Range Fracture Zone high. Hence, an additional source for the material is probably necessary. In contrast to Veevers and Powell (1979) and Boote and Kirk (1989), we believe that an uplifted Pilbara Block cannot have been a major source, because sedimentation rates dropped drastically after breakup. Had the broad, tectonically stable Pilbara Block been the dominant source of Barrow Group sediments, there is no tectonic reason why it should not have continued to shed material at similar rates later in the Neocomian. This large volume of material would 

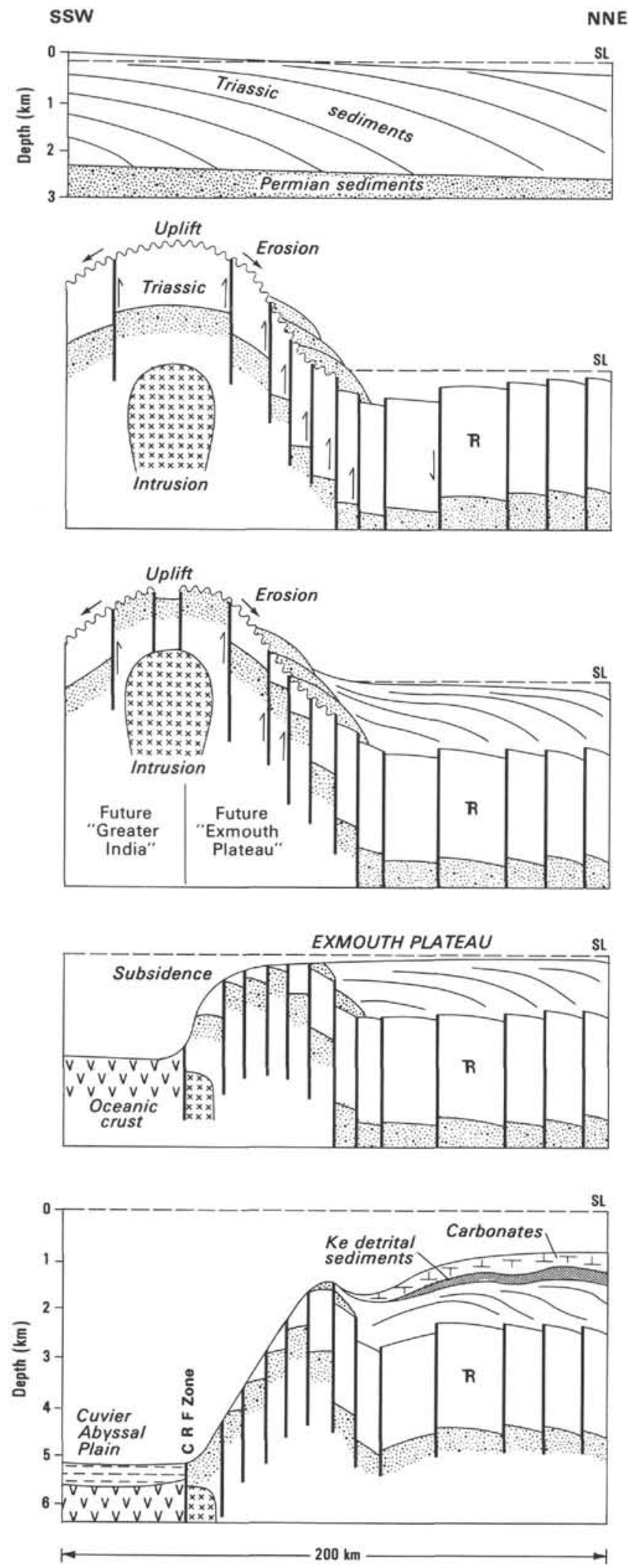

\section{LATEST TRIASSIC}

Delta prograding to north. Jurassic rifting later established major faults in Triassic sequence. Little Jurassic sedimentation.

\section{EARLY BERRIASIAN}

Rapid uplift associated with commencement of thermal doming along CRFZ. Southern sediment sources cut off. Uplifted area eroded and Berriasian sediments deposited. Intrusion at depth along CRFZ.

\section{LATE BERRIASIAN}

Continuing uplift associated with thermal doming along CRFZ. Massive erosion of uplifted area has led to deposition of thick Barrow delta building north.

\section{HAUTERIVIAN}

Greater India has cleared Exmouth Plateau by moving off to WNW along CRFZ. Oceanic crust injected and starts to cool, carrying SW plateau margin down with it. Barrow delta source has vanished and deposition slowed greatly.

\section{PRESENT DAY}

SW margin of Exmouth Plateau has collapsed as Cuvier Abyssal Plain developed. Exmouth Plateau sedimentation predominantly bathyal carbonates from Late Cretaceous times. Abyssal sediments on plain.

Figure 17. Schematic cross sections showing the structural evolution of the southwestern margin of the Exmouth Plateau, based on seismic profiles 17/062 and 17/063 (Figs. 15 and 16; location in Fig. 2). The main feature is the uplift of the margin in the Berriasian by thermal doming and the contribution to the formation of the Barrow delta by its erosion. ValanginianHauterivian seafloor spreading removed Greater India to the west-northwest along the Cape Range Fracture Zone and formed the Cuvier Abyssal Plain and the Exmouth Plateau, as discussed in detail in "Sedimentary and Tectonic Implications." 
have been deposited either on the plateau or, more likely, on the rapidly subsiding Cuvier Abyssal Plain, but there is no evidence for it in either location.

We agree with Boyd et al. (this volume) and Exon et al. (this volume, chapter 12) that one additional major source for the Barrow delta was probably the area to the southeast, where thermal doming was taking place above the future north-south spreading center of the Cuvier Abyssal Plain. An additional source of steady but limited supply was the Pilbara Block. Once the southern and southeastern sediment sources were cut off, with Valanginian breakup, the Pilbara Block became the sole detrital source of sediment for the plateau, and formed wedges of sediment on the eastern plateau in the late Neocomian, Aptian, and Albian (Boyd et al., this volume).

5. The newly recognized lower Neocomian sediment body that fills the depression between the planated volcanic ridges on the westernmost plateau (Figs. 6, 10, and 14) is equivalent to the Barrow Group. The general lack of Jurassic and lower Neocomian sediments in this area suggests that the outer plateau margin may have been a sediment-starved broad regional uplift throughout that period. This had been an area of active rifting through the Late Triassic and much of the Jurassic and of volcanism in the latest Triassic and earliest Jurassic.

The planation of the volcanic highs along the western margin may have started early in the Jurassic, but the latest Jurassic to early Neocomian tectonic movements associated with breakup introduced a new element, and local sedimentation commenced. Figure 14 suggests that the new element was the lowering of the central ridge and the intervening low in the volcanic surface, along steeply dipping faults between 74.1500 and 74.1600. Thereafter, sediment could fill the resultant depression by prograding eastward, away from the western ridge that was still part of an eroding regional high. Its acoustic character suggests that the prograding material was a mixture of sand and mud, but that in places this was reworked to form sand bodies (e.g., mound between 74.1300 and 74.1400 in Fig. 14). These sediments are almost certainly the source of the early Neocomian spores recorded in the upper Neocomian sediments at the base of the nearby Site 766 (A. McMinn, pers. comm., 1990).

6. The breakup of the northwestern margin of the Exmouth Plateau occurred at the same time (early Neocomian) as the southwestern margin, as attested to by our seismic studies, the magnetic anomaly recognition of Fullerton et al. (1989), and the age of the sediments on basement at Site 766 (Fig. 4). However, the northwestern margin formed by rifting, with the magnetic anomalies subparallel to the margin (Fig. 10).

Fullerton et al. (1989) showed several oceanic fracture zones parallel to the Cape Range Fracture Zone that should impact on the margin. There is a clear offset in the margin at about $18^{\circ} \mathrm{S}, 111^{\circ} 30^{\prime} \mathrm{E}$ (Fig. 10), which does not correspond with any known oceanic fracture zone. Seismic evidence shows that this offset separates the continental volcanic basement of the plateau from oceanic crust. It trends roughly northwest, and at least $40 \mathrm{~km}$ of continental volcanic basement appears to have been removed from its northern side during breakup.

Breakup produced a margin bounded by normal faults and fracture zones. Immediately after breakup, fairly deep water (approximately $800-1000 \mathrm{~m}$ ) bounded the margin to the west, as shown by the basal (VH) sediments at Site 766. A gentle oceanward tilt of the planated volcanic basement developed (Fig. 13) as the oceanic crust cooled and sank, pulling the continental margin down.
7. The exact dating of breaking on the northwestern margin is documented by Site 766, drilled near the southeastern edge of the Gascoyne Abyssal Plain. According to Fullerton et al. (1989) the site is on anomaly M10 (Fig. 10) and breakup was slightly earlier, at about 134 m.y. on the Harland et al. (1982) time scale they used. Both Harland et al. (1982) and Haq et al. (1987) would date this breakup as Valanginian. The basement of basaltic sills with thin interbeds of uppermost Valanginian sediments and overlain by glauconitic bathyal sandstone and siltstone (lithostratigraphic Subunit 3B and seismic sequence VH of Fig. 4) that was drilled at Site 766 was dated as late Valanginian and Hauterivian by palynology (Ludden, Gradstein, et al., 1990). These results suggest that breakup along the northwestern margin of the Exmouth Plateau occurred in the late Valanginian.

8. The lack of upper Valanginian and lower Hauterivian sediments on the Exmouth Plateau contrasts with the situation at Site 766, where sediments of this age rest on oceanic crust. Brenner (this volume, chapter 31 ) has shown that Sites 762 and 763 both contain Berriasian and lowermost Valanginian deltaic mudstone of the Barrow Group, overlain disconformably by middle Hauterivian to Barremian shallow-marine mudstones. Three dinoflagellate subzones (Phoberocysta burgeri, Senoniasphaera tabulata, and Systematophora areolata) are missing, representing about 7 m.y. There are no major time breaks in the overlying Barremian, Aptian, or Albian sequences (Brenner, this volume, chapter 31).

Why this time break (essentially Valanginian) is present on the plateau, but not at Site 766 , is uncertain. Perhaps the general lack of detrital input to the plateau after Greater India departed, and the probability that this was a time of relatively rapid rise in sea level following major drops (see the sea-level curve of Haq et al., 1987), led to sediment starvation. Alternatively, tectonic movements, as the plateau adjusted to new isostatic conditions, may have caused the break. Earthquakes related to tectonism conceivably could have removed what sediments were deposited, by mass flow to the surrounding deep-water areas. Possibly, the area actually may have risen above sea level in an initial adjustment to the removal of Greater India. In this case, it would have been a vast muddy plain with no hinterland, on which almost no deposition took place.

9. A general model for the geological development of the southwestern margin of the Exmouth is presented in Figure 17. The plateau was firmly linked to Greater India in the Triassic and Jurassic. The Triassic saw northerly prograding of fluviodeltaic sediments across the region. The Jurassic was a time of little deposition, indicating that the region was high, perhaps because of thermal effects associated with rifting. In the latest Jurassic and Berriasian, there was major uplift along the length of the future Cape Range Fracture Zone, along normal faults produced by thermal doming immediately prior to breakup. Erosion stripped Triassic and Permian sediments from it, and deposited them rapidly across the southern plateau as part of the Berriasian to early Valanginian Barrow delta.

Valanginian breakup, along the Cape Range Fracture Zone by west-northwest-oriented transcurrent faulting, removed Greater India and left behind the basalts in the Cuvier Abyssal Plain. The outermost margin of the plateau subsided along preexisting and new faults, in harmony with the cooling abyssal plain basalts. However, the inner part of the Cape Range Fracture Zone uplift was preserved as a high, presumably because of igneous buttressing at depth, and the margin as a whole formed an anticlinorium. 


\section{CONCLUSIONS}

1. A broad band of acoustic basement rings much of the western corner of the Exmouth Plateau. This almost certainly consists of early rift volcanics and is probably of latest Triassic and earliest Jurassic age.

2. A thick, faulted Triassic sequence is directly overlain by thick deltaic Barrow Group sediments of early Neocomian age. The deltaic sediments have been mapped, and prograde to the north-northwest away from the present-day Cuvier Abyssal Plain.

3. Breakup in the late Valanginian saw Greater India move away to the west-northwest, along the Cape Range Fracture Zone in the south and by rifting in the northwest.

4. Prior to breakup, thermal effects formed marginal uplifts. We suggest that latest Jurassic to early Neocomian uplift along the Cape Range Fracture Zone provided a sediment source for the western Barrow Group, which is up to $1500 \mathrm{~m}$ thick and was deposited in the Berriasian and early Valanginian over about $6 \mathrm{~m} . \mathrm{y}$. Another major sediment source was probably a broad uplift above the future north-south spreading center that was to form the eastern edge of the Cuvier Abyssal Plain.

5. Wave erosion of highs in the rift volcanics along the northwestern margin provided sediment for a large, shallowmarine body of sediment, separate from but equivalent to the Barrow Group. This prograded from the west and filled a new depression caused by fault movements associated with breakup.

6. Immediately after breakup, there was a late Valanginian to earliest Hauterivian hiatus on the plateau, which corresponds to initial deeper water detrital sedimentation on basalt sills at Site 766, just west of the plateau. The reason for the hiatus is unclear, but the lack of nearby land, and hence lack of detrital input, was clearly important. The worldwide rise of sea level at the time may also have played a major role.

7. Deep intrabasement reflectors cut the Triassic sediments and the Triassic-Jurassic rift volcanics. They generally deepen toward the center of the plateau and appear to be sills, although some may coincide with detachments. Their age is constrained as Jurassic, and they may well be related to the later rifting in Middle to earliest Late Jurassic times, as the products of partial melting caused by the decompression of upwelling asthenosphere.

8. The Hauterivian to Cenomanian sequence on the plateau has been further documented. The major Cretaceous units at Sites 762 and 763 are mappable seismically to the plateau margins. They reflect the subsidence of the plateau and the onset of pelagic carbonate deposition.

\section{ACKNOWLEDGMENTS}

The authors are grateful to the other members of the shipboard scientific parties of ODP Legs 122 and 123, for the detailed shipboard work on Sites 762, 763, and 766 and for various discussions about the seismic profiles in their vicinity. They are especially grateful to Ron Boyd and Wolfram Brenner for providing early copies of their papers in this volume that are relevant to the western Exmouth Plateau. The figures were drawn in the BMR drawing office, and the text was typed by Pat Burrell at BMR. Paul Williamson (BMR) reviewed an early copy of the paper, and John Veevers (Macquarie University, Sydney) is thanked for his referee report. Exon publishes with the permission of the Executive Director, Bureau of Mineral Resources, Canberra, Australia. This is University of Texas Institute of Geophysics Contribution no. 860 .

\section{REFERENCES}

Audley-Charles, M. G., 1988. Evolution of southern margin of Tethys (North Australian region) from early Permian to Late Cretaceous. In Audley-Charles, M. G., and Hallam, A. (Eds.), Tethys and Gondwana. Geol. Soc. Spec. Publ. London, 37:79-100.

Barber, P. M., 1982. Paleotectonic evolution and hydrocarbon genesis of the central Exmouth Plateau. APEA J., 22(1):131-144.

1988. The Exmouth Plateau deep water frontier: a case history. In Purcell, P. G., and Purcell, R. R. (Eds.), The North West Shelf, Australia: Proc. Pet. Expl. Soc. Aust. Symp., 173-187.

Boote, D.R.D., and Kirk, R. B., 1989. Depositional wedge cycles on evolving plate margin, western and northwestern Australia. AAPG Bull., 73:216-243.

Bradshaw, M. T., Yeates, A. N., Beynon, R. M., Brakel, A. T., Langford, R. P., Totterdell, J. M., and Yeung, M., 1988. Paleogeographic evolution of the North West Shelf Region. In Purcell, P. G., and Purcell, R. R. (Eds.) The North West Shelf, Australia: Proc. Pet. Expl. Soc. Aust. Symp., 29-54.

Buffler, R. T., Rowell, P., and Exon, N. F., in press. Seismic stratigraphy of the Site 766 area, southwestern margin of the Exmouth Plateau, Australia. In Ludden, J. N., Gradstein, F. M., et al., Proc. ODP, Init. Repts., 123: College Station, TX (Ocean Drilling Program).

Cockbain, A. E., 1989. The North West Shelf. APEA J., 29(1):529545.

Colwell, J. B., Graham, T. L., and Shipboard Party, 1990. Stratigraphy of Australia's NW continental margin (Project 121-26). Bur. Min. Resour. Aust. Rec., 1990/85.

Cook, A. C., Smyth, M., and Vos, R. G., 1985. Source potential of Upper Triassic fluvio-deltaic systems of the Exmouth Plateau. APEA J., 25(1):204-215.

Erskine, R., and Vail, P. R., 1988. Seismic stratigraphy of the Exmouth Plateau. In Bally, A. W. (Ed.), Atlas of Seismic Stratigraphy (vol. 2). AAPG Stud. in Geol., 27:163-173.

Exon, N. F., von Rad, U., and von Stackelberg, U., 1982. The geological development of the passive margins of the Exmouth Plateau off northwest Australia. Mar. Geol., 47:131-152.

Exon, N. F., and Willcox, J. B., 1976. Mesozoic outcrops on the lower continental slope off Exmouth, Western Australia. BMR J. Aust. Geol. Geophys., 1:205-209.

1978. Geology and petroleum potential of the Exmouth Plateau area off Western Australia. AAPG Bull., 62:40-72.

1980. The Exmouth Plateau: stratigraphy, structure and petroleum potential. Bull. Bur. Miner. Resour. Geol. Geophys. Aust., 199.

Exon, N. F., and Williamson, P. E., 1988. Preliminary post-cruise report, Rig Seismic Research Cruises 7 \& 8: sedimentary basin framework of the northern and western Exmouth Plateau. Bur. Min. Resour. Aust. Rec., 1988/30.

Falvey, D. A., and Veevers, J. J., 1974. Physiography of the Exmouth and Scott plateaux, Western Australia, and adjacent northeast Wharton Basin. Mar. Geol., 17:21-59.

Falvey, D. A., and Williamson, P. E., 1988. Preliminary post-cruise report, Rig Seismic Research Cruises 7 \& 8: deep seismic structure of the Exmouth Plateau. Bur. Miner. Resour. Aust. Rec., 1988/31.

Fullerton, L. G., Sager, W., and Handschumacher, D. W., 1989. Late Jurassic-Early Cretaceous evolution of the eastern Indian Ocean adjacent to Northwest Australia. J. Geophys. Res., 94:2937-2953.

Haq, B. U., Hardenbol, J., and Vail, P., 1987. Chronology of fluctuating sea levels since the Triassic ( 250 million years ago to present). Science, 235:1156-1166.

Haq, B. U., von Rad, U., O'Connell, S., et al., 1990. Proc. ODP, Init. Repts., 122: College Station, TX (Ocean Drilling Program).

Harland, W. B., Cox, A. V., Llewellyn, P. G., Pickton, C.A.G., Smith, A. G., and Walters, R., 1982. A Geologic Time Scale: Cambridge (Cambridge Univ. Press).

Helby, R., Morgan, R., and Partridge, A. D., 1987. A palynological zonation of the Australian Mesozoic. In Jell, P. A. (Ed.), Studies in Australian Mesozoic Palynology. Mem. Assoc. Australas. Palaeontol., 4:1-94.

Hocking, R. M., Moors, M. T., and van der Graaff, W.J.E., 1987. Geology of the Carnarvon Basin, Western Australia. Bull.-Geol. Surv. West. Aust., 133. 
Johnson, B. D., Powell, C. McA., and Veevers, J. J., 1976. Spreading history of the eastern Indian Ocean and greater India's northward flight from Antarctica and Australia. Geol. Soc. Am. Bull., $87: 1560-66$.

Larson, R. L., 1977. Early Cretaceous breakup of Gondwanaland off Western Australia. Geology, 5:57-60.

Larson, R. L., Mutter, J. C., Diebold, J. B., Carpenter, G. B., and Symonds, P. A., 1979. Cuvier Basin: a product of ocean crust formation by Early Cretaceous rifting off western Australia. Earth Planet. Sci. Lett., 45:105-114.

Leg 123 Shipboard Scientific Party, 1988. Sedimentology of the Argo and Gascoyne abyssal plains, NW Australia: report on Ocean Drilling Program Leg 123 (Sept. 1-Nov. 1, 1988). Carbon. Evapor., 3:201-212.

Ludden, J. N., Gradstein, F. M., et al., 1990. Proc. ODP, Init. Repts., 123: College Station, TX (Ocean Drilling Program).

Markl, R. G., 1974. Evidence for the breakup of eastern Gondwanaland by the Early Cretaceous. Nature, 251:196-200.

Mutter, J. C., Larson, R. L., and Northwest Australia Study Group, 1989. Extension of the Exmouth Plateau, offshore northwestern Australia: deep seismic reflection/refraction evidence for simple and pure shear mechanisms. Geology, 17:15-18.

Pigram, C. J., and Panggabean, H., 1984. Rifting of the northern margin of the Australian continent and the origin of some microcontinents in Eastern Indonesia. Tectonophysics, 107:331-53.

Powell, C. McA., Roots, S. R., and Veevers, J. J., 1988. Pre-breakup continental extension in East Gondwanaland and the early opening of the eastern Indian Ocean. Tectonophysics, 155:261-283.

Powell, D. E., 1976. The geological evolution and hydrocarbon potential of the continental margin off northwest Australia. APEA J., 16(1):13-24.

Purcell, P. G., and Purcell, R. R. (Eds.), 1988. The North West Shelf, Australia: A Case History: Proc. Pet. Expl. Soc. Aust. Symp.

Scotese, C. R., 1986. Phanerozoic reconstructions: a new look at the assembly of Asia. Univ. Texas Inst. Geophys. Tech. Rep., 66.

Scrutton, R. A., 1979. On sheared passive continental margins. Tectonophysics, 59:293-305.

Sengör, A.M.C., 1985. The story of Tethys: how many wives did Oceanos have? Episodes, 8:3-12.

Stagg, H.M.J., and Exon, N. F., 1981. The geology of the Scott Plateau and Rowley Terrace. Bur. Miner. Resour. Aust. Bull., No. 213.

Veevers, J. J., 1988. Morphotectonics of Australia's northwestern margin: a review. In Purcell, P. G., and Purcell, R. R. (Eds.), The North West Shelf, Australia: Proc. Pet. Expl. Soc. Aust. Symp., 19-27.

Veevers, J. J., and Cotterill, D., 1979. Western margin of Australia: a Mesozoic analogue of the East Africa rift system. Geology, $4: 713-717$
Veevers, J. J., Heirtzler, J. R., et al., 1974. Init. Repts. DSDP, 27: Washington (U.S. Govt. Printing Office).

Veevers, J. J., and Powell, C. McA., 1979. Sedimentary wedge progradation from transform-faulted continental rim: southern Exmouth Plateau, western Australia. AAPG Bull., 63:2088-2096.

Veevers, J. J., Tayton, J. W., Johnson, B. D., and Hansen, L., 1985. Magnetic expression of the continent-ocean boundary between the western margin of Australia and the eastern Indian Ocean. $J$. Geophys., 56:106-120.

von Rad, U., and Exon, N. F., 1983. Mesozoic-Cenozoic sedimentary and volcanic evolution of the starved passive continental margin off northwest Australia. In Watkins, J. S., and Drake, C. L. (Eds.), Studies in Continental Margin Geology: AAPG Mem., 34:253281.

von Rad, U., Thurow, J., Haq, B. U., Gradstein, F., Ludden, J., and ODP Leg 122/123 Shipboard Scientific Parties, 1989. Triassic to Cenozoic evolution of the NW Australian continental margin and the birth of the Indian Ocean (preliminary results of ODP Legs 122 and 123). Geol. Rundsch., 78:1189-1210.

von Stackelberg, U., Exon, N. F., von Rad, U., Quilty, P., Shafik, S., Beiersdorf, H., Seibertz, E., and Veevers, J. J., 1980. Geology of the Exmouth and Wallaby Plateaus off northwest Australia: sampling of seismic sequences. BMR J. Aust. Geol. Geophys., 5:113140.

White, R. S., Spence, G. D., Fowler, S. R., McKenzie, D. P. Westbrook, G. K., and Bowen, A. N., 1987. Magmatism at rifted continental margins. Nature, 330:439-444.

Willcox, J. B., and Exon, N. F., 1976. The regional geology of the Exmouth Plateau. APEA J., 16(1):1-11.

Williamson, P. E., Swift, M. G., Kravis, S. P., Falvey, D. A., and Brassil, F., 1990. Permo-Carboniferous rifting of the Exmouth Plateau region, Australia: an intermediate plate model. In Pinet, B., and Bois, C. (Eds.), The Potential of Deep Seismic Profiling for Hydrocarbon Exploration: Paris (Editions Technip), 235-248.

Wright, A. J., and Wheatley, T. J., 1979. Trapping mechanisms and the hydrocarbon potential of the Exmouth Plateau. APEA J., 19(1):19-29.

Yeates, A. N., Bradshaw, M. T., Dickins, J. M., Brakel, A. T., Exon, N. F., Langford, R. P., Mulholland, S. M., Totterdell, J. M., and Yeung, M., 1986. The Westralian Superbasin: an Australian link with Tethys. In McKenzie, K. G. (Ed.), Shallow Tethys 2. Proc. Int. Symp. Shallow Tethys, Wagga Wagga. Rotterdam (A. A. Balkema), 199-213.

Date of initial receipt: 23 July 1990 Date of acceptance: 13 March 1991 Ms 122B-125 